\title{
Jhering en Ortega y Gasset
}

\section{Jhering in Ortega y Gasset}

\author{
Autor: \\ Juan José Gil Cremades \\ Universidad de Zaragoza, Espańa \\ jjgilcremades@gmail.com \\ https://orcid.org/0000-0002-2704-9352 \\ Recibido: 8-4-2019 \\ Aceptado: 13-11-2019

\section{Citar como:} \\ Gil Cremades, Juan José, (2020). Jhering en Ortega \\ y Gasset. Doxa. Cuadernos de Filosofía del Derecho, \\ 43, pp. 31-58. https://doi.org/10.14198/ \\ DOXA2020.43.02

\section{Licencia:} \\ Este trabajo se publica bajo una Licencia Creative \\ Commons Atribución 4.0 Internacional.

\section{(c) (i)}

(C) Juan José Gil Cremades

\section{Juan José Gil Cremades}

\section{Resumen}

A partir de 1933, abandonada la política activa, Ortega dedicó su atención, entre otros temas, a la filosofía social; particularmente a desentrañar el "hecho social», que creyó radicaba en los «usos», quizá bajo la inspiración de Jhering. Cómo llegó a él, fallecido en 1892, qué lectura hizo de su obra, cómo modificó sus planteamientos y cómo su propuesta fue recibida por la coetánea filosofía española del derecho, son las cuestiones estudiadas en este trabajo.

Palabras clave: Jhering; Ortega y Gasset; hecho social; uso social.

\begin{abstract}
After 1933, when he abandoned active politics, Ortega devoted his attention, among other topics, to social philosophy; particularly to unraveling the "social fact», which he believed was rooted in "customs», perhaps under the inspiration of Jhering. How he came to it, died in 1892, what reading he made of his work, how he modified his approaches and how his proposal was received by the contemporary spanish philosophy of law are the questions studied in this work.
\end{abstract}

Keywords: Jhering; Ortega y Gasset; social fact; social use. 


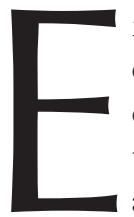

n los primeros lustros de este siglo ha crecido en Espańa el número de las ediciones de obras de Rudolf Jhering, las más de ellas manteniendo las traducciones aparecidas entre 1881 y 1911. Después de esas fechas, solo hubo una traducción parcial de Jurisprudencia en broma y en serio (1933) y la edición abreviada de El Espiritu del derecho romano, promovida por Ortega y Gasset, pero publicada en Buenos Aires (1947). Luego, el largo silencio que la dictadura impuso a Jhering, obligó a acudir a las diversas reediciones realizadas en la América de habla hispana de las traducciones madrileñas finiseculares ${ }^{1}$. La recuperación de Jhering en España se produjo a partir de de 1985, y solo con intermitencias². Pero, desde 1999, hay un alud de ediciones, que salvo excepciones, reproducen las del $\mathrm{xIX}^{3}$. Casualmente en ese mismo intervalo sale a la luz una nueva edición de la obra completa de Ortega y Gasset (Fundación Ortega/Marańón, Taurus), que nos destaca, aunque no por vez primera, el interés del filósofo español por Jhering, al abordar el tema jurídico ${ }^{4}$.

A partir de 1933, abandonada la política activa, Ortega dedicó su atención, entre otros temas, a la filosofía social; particularmente a desentrañar el «hecho social», que creyó radicaba en los «usos», quizá bajo la inspiración de Jhering. Cómo llegó a él, fallecido en 1892, qué lectura hizo de su obra, cómo modificó sus planteamientos y cómo su propuesta fue recibida por la coetánea filosofía española del derecho, son las cuestiones estudiadas en este trabajo.

\section{RECEPCIÓN DE JHERING EN ESPAÑA}

No voy a desarrollar este tema, ya estudiado tempranamente por mí, sino a sintetizar y rectificar, en su caso, lo que entonces expuse de forma dispersa ${ }^{5}$, y a lo que en 1970 puso orden y aumentó en información Rafael Gibert ${ }^{6}$, en su contribución a un notable simposio celebrado en Göttingen con ocasión del 150 aniversario del nacimiento de

1. Con excepción de la traducción completa de los dos volúmenes de El fin en el derecho, hecha en el exilio por el anarquista español D. Abad de Santillán, seudónimo de Sinesio Baudillo (Cajica, Puebla [México], 1961-1962).

2. La pionera traducción de A. Posada, con prólogo de L. Alas, de La lucha por el derecho (Civitas, 1985), y en la misma editorial jurídica, en 1987, la versión íntegra de Bromas y veras en la ciencia jurídica. En 1993 el romanista E. Valiño tradujo, no del alemán, el libro de "casos jurídicos», El derecho en la vida cotidiana (tirant lo blanch).

3. Las excepciones son: ¿Es el derecho una ciencia? (Comares, 2002) y Sobre el nacimiento del sentimiento jurídico (Trotta, 2008), ambas conferencias traducidas por F. Fernández-Crehuet. Comares reedita la méxicana de $E l$ fin en el derecho, ya reseñada.

4. Robles, G., «La filosofía jurídica de Ortega: el derecho como uso social y la justicia como valor», Meditaciones sobre Ortega y Gasset (Llano, F. H.; Castro, A, eds.)., Tébar, Madrid, 2005, 569-592. En pág. 570: «Se dice que, por la época en que murió, estaba embarcado en el estudio de la obra de Rudolf von Ihering y que en su mesa de trabajo se encontraba el libro de este insigne jurista germano titulado Der Zweck im Recht («El fin en el derecho")"

5. Cfr. Gil Cremades, J. J., El reformismo español. Krausismo, escuela histórica, neotomismo, Ariel, Barcelona, 1969. En el registro de personas, pág. 401, pueden consultarse varias remisiones a Jhering.

6. Gibert, R., "Jhering en España», en: Jherings Erbe. Göttinger Symposion zur 150 Wiederkehr des Geburtstags von Rudolph von Jhering, Vandenhoeck \& Ruprecht, Göttingen 1970, 40-67-En págs. 42, n. 3; 45, n.9; 52,

Doxa. Cuadernos de Filosofía del Derecho, (2020), 43, pp. 31-58 
Jhering. Como punto de partida, puede decirse que la primera referencia del jurista alemán aparece en 1853 en la Revista General de Legislación y Jurisprudencia, fundada ese mismo año, en una nota anónima que da noticia de la publicación en Leipzig en 1852 del primer tomo de Espiritu ${ }^{7}$. Esta revista jurídica, hoy todavía viva, cumpliendo lo prometido a sus lectores, de «hacerles conocer los incesantes y profundos trabajos de la pensadora Alemania» ${ }^{8}$, siguió la pista de la continuidad de la obra: Emilio Reus, hijo del fundador de la revista, publicó en 1878, una reseña de la segunda edición de la traducción francesa de la obra completa ${ }^{9}$, advirtiendo que el autor, aunque hubiera arrancado de los planteamientos de la Escuela histórica, e incluso superara metodológicamente a Savigny, en los dos últimos tomos derivaba hacia planteamientos claramente "positivistas». Apreciación propia de lector atento.

En esos veinticinco años que median entre una y otra noticia, la $R G L J$ se consolida como referencia obligada de la vida jurídica española. Proceso que va al socaire de las vicisitudes del régimen liberal español, que está poniendo lentamente en pié sus estructuras jurídicas. Y todo ello desde la peculiar idiosincrasia de su director y cofundador José Reus García, responsable de la dimensión empresarial, y de la de quien fuera, desde 1858, su orientador intelectual: Pedro Gómez de la Serna, catedrático y exministro efímero (mayo a julio de 1843) de Gobernación en la Regencia del general Espartero. Fiel a este, fue toda su vida política un prohombre del Partido progresista. Cuando se vincula a la Revista, ha tenido lugar el «pronunciamiento» del general O'Donnell (1854), desgajado del moderantismo y proclive a entenderse con Espartero y con una escisión del progresismo: el Partido demócrata en cuyas filas milita el convencido masón José Reus, diputado de las Cortes constituyentes de ese último año, que fracasan en su propósito de dotar a la Monarquía de una nueva Constitución. En ese trance político, a de la Serna le fue confiada brevemente (junio a julio de 1854) la cartera ministerial de Gracia y Justicia. Tras esta aventura política, de la Serna vuelve a sus ocupaciones intelectuales: ocupa la presidencia de la Real Academia de Jurisprudencia y Legislación (1856) y, durante algo más de un decenio, es un redactor fecundo -entre diez y quince colaboraciones al año- de la Revista ${ }^{10}$. Ya en el «sexenio revolucionario» (1869-1874), la presencia de esas dos tendencias políticas, acompañada por la progresiva formación, a partir del Partido demócrata, de un republicanismo no consolidado, Gómez de la Serna será Presidente del Tribunal Supremo a comienzos del breve reinado de Amadeo I, muriendo en diciembre de 1871, el mismo año de su nombramiento. Reus, por su parte, será Senador demócrata en esa misma fase del sexenio.

n. 16 d; 53 , n. 19 y 61 n. 44 se hacen referencias a aportaciones contenidas en mi trabajo, citado en la nota anterior, presentado como tesis doctoral en la Universidad Complutense en 1965.

7. Revista General de Legislación y Jurisprudencia (RGLJ) 2 (1853) 128. En adelante, cuando nos refiramos a la trilogía fundamental de la obra de Jhering: Geist, Kampfy Zweck, lo haremos con los vocablos en español: Espiritu, Lucha, Fin, respectivamente, pero utilizando los vocablos alemanes cuando citemos ediciones originales.

8. RGLJ3 (1854) pág. V.

9. RGLJ 52 (1878) pág. 126.

10. Cfr. Ruiz Ballón, A., Pedro Gómez de la Serna (1806-1871). Apuntes para una biografía jurídica, Universidad Carlos III, Madrid, 2013, 353 págs. (DD PP DH. Monografías. Serie Historia del Derecho 17). 
Pero no abandonemos a Gómez de la Serna, y olvidemos un episodio crucial en la crónica de la presencia de Jhering en Espańa. Ese mismo 1871 apareció la segunda edición de la especial traducción, compatible «con el carácter y necesidades morales de mi pueblo», que Sanz de Río había hecho, del Ideal de la humanidad para la vida, de C. Chr. F. Krause ${ }^{11}$. La primera edición databa de $1860^{12}$, y en ambas, idénticas, se reprodujo la dedicatoria al «Excmo. Sr. D. Pedro Gómez de la Serna». En su capítulo de gracias, Sanz del Río recordaba que, en 1843, Gómez de la Serna, Ministro de Gobernación, había hecho posible su viaje a Europa, que le había puesto en contacto con el krausismo. Baste recordar el calvario que supuso esa primera edición para Sanz del Río: apertura de expediente, expulsión de la cátedra, inclusión del libro en el Indice. Mas esa segunda edición era póstuma -Sanz del río había muerto en 1869-, y aparecía oportunamente en el sexenio por iniciativa de los fideicomisarios, que habían hecho posible la presencia activa de los krausistas en la Universidad Central gracias al «memorable decreto que afirmó para siempre la libertad de la Ciencia y la Enseńanza», tal como se había proclamado en la Constitución de 1869. Entre esos fideicomisarios figuraban: Fernando de Castro, nombrado desde el inicio del sexenio Rector de la Universidad Central; Francisco Giner quien, con discreción, sería el mentor durante decenios de la proyección social del krausismo español; Nicolás Salmerón, presidente durante mes y medio de la I República en 1873 y catedrático de metafísica en la Central, cátedra en la que le sucederá Ortega y Gasset.

La difusión de Jhering se producirá ya en la Restauración, y no por propiciarla el régimen político, que pronto mostró su carácter represivo con los profesores universitarios, protagonistas durante el «sexenio». Sin embargo, fue Antonio María Fabié, «amigo político» de Antonio Cánovas -el «empresario» de ese régimen, según el joven Ortega-, quien, en 1878, desde la tribuna del Ateneo madrileño, habló de Jhering como si fuera el dernier cri de la "ciencia del derecho»" ${ }^{13}$. Fabié, sevillano, había estudiado en la Universidad hispalense, residencia de una escuela hegeliana, a la que se adscribió, con tanta superficialidad como machaconería, hasta el punto de ser criticado por esto último en el Parlamento o en los Heterodoxos de Menéndez Pelayo. Pero no era dogmático, pues en el ámbito de un Estado confesional, que por ello restringía la libertad de cátedra, dirá de la «doctrina escolástica», que «en mi concepto no es la filosofía en general: al fin es una filosofía». Inicialmente hace un repaso tanto del individualismo racionalista liberal, como del estatalismo hegeliano y del krausista que en el caso español vincula,

11. Krause, C. Chr. F., Ideal de la Humanidad para la vida, con introducción y comentarios de D. Julián Sanz del Río. Segunda edición, Imprenta de F. Martínez García, Madrid, 1871. La cita que se hace más adelante corresponde a la pág. VII.

12. Krause, C. Ch. (sic), Ideal, cit., Imprenta de Manuel Galiano, Madrid, 1860. El traductor indicaba en portada ser Catedrático de Historia de la Filosofía en la Universidad Central. En página sin numerar [X] se contiene la dedicatoria.

13. Fabié, A. M., Estado actual de la ciencia del derecho. Conferencia dada en el Ateneo de Madrid el miércoles 22 de noviembre de 1878 por..., Consejero de Estado, Imprenta de la Revista de Legislación, Madrid, 1879, 16 págs. Las citas en págs. 3, 8. 10, 14, sucesivamente. Sobre él mi: «El pensamiento jurídico de la España de la Restauración», Discordia concors, vol. II, Comares, Granada, 2015, págs. 33, 39, 54.

Doxa. Cuadernos de Filosofía del Derecho, (2020), 43, pp. 31-58 
con buenas razones, a Henri Ahrens. Todas estas corrientes son metodológicamente teorías deductivistas. Y este es el sesgo actual: construir una ciencia del derecho desde el inductivismo, desde la experiencia. De antemano no oculta su postura: "Jamás en mi concepto llegaría a crearse una ciencia del derecho ni a exponerse ninguna de las ramas de la ciencia social, procediendo por vía de observación, y empleando el método inductivo". Pero ello, no le detiene para exponer algunas corrientes coetáneas que van en esa dirección. Una de ellas es la de Jhering, que del estudio de las instituciones del derecho del pueblo romano, «influido por la metafísica de la escuela hegeliana, se ha elevado a conceptos que son de indudable transcendencia». De Espiritu ha pasado a un «breve, muy breve» libro. «Este libro se denomina La lucha por el Derecho, y revela una tendencia práctica que se funda en los principios de la dialéctica hegeliana». La ocasión del libro se propone en tono de chismorreo: «... se dice que fue escrito bajo la inspiración del Canciller Príncipe de Bismark (sic) para justificar su política invasora, y hasta tiene un título que parece quitarle todo valor científico». Por lo demás -insiste-, hay que vincular las tesis del libro a la dialéctica hegeliana.

Esa noticia es coetánea a la presencia de obras de Jhering en las bibliotecas de altas instituciones jurídicas, por ejemplo, en la de la Academia de Jurisprudencia y Legislación ${ }^{14}$, por supuesto en sus traducciones francesas ${ }^{15}$. En el xIx, esa aduana cultural francesa era necesario atravesarla, en este caso, para acceder, ya desde Savigny, a la bibliografía jurídica alemana ${ }^{16}$. Pero si de Savigny, hasta la Restauración, solo se tradujo al castellano una obra, por supuesto a partir de la anterior versión frances $\mathrm{a}^{17}$, de Jhering, por contra, entre fines del XIx y principios del xx, se traducirá, con las limitaciones que advertiremos, el grueso de su obra. No es cuestión de la mayor o menor relevancia alcanzada entre nosotros por uno u otro jurista ${ }^{18}$; la razón de la amplia diferencia entre el

14. Torres Campos, M., Catálogo sistemático de las obras existentes en la Biblioteca de la Academia de Jurisprudencia y Legislación formado por..., Bibliotecario de la misma, Imprenta del Ministerio de Gracia y Justicia, Madrid, 1876.

15. En el Catálogo citado se incluye: Le combat pour le drot, traduit par A. F. Meydieu, Vienne, 1875 (cfr. pág. 44), así como: Du fondement de la protection possesoire. Revision de la théorie de la possesion, $2 e$ édition, ed. O. de Meulenare, Gand, 1875 (cfr. pág. 187). Se incluyen los datos aducidos por Torres Campos. Pueden completarse en: Losano/ M. G./ Bonazzi, E., Bibliografie di Jhering e Gerber, Giuffrè Editore, Milano, 1978, págs. 38 y 39 .

16. Por ello, aunque sea solo un esbozo, remitimos a: Whitman, J.Q.; Wachsmann, P., «Jhering parmi les Français, 1870-1918", Annales - Faculté de Droit de Strasbourg (La science juridique française et la science juridique allemande de 1870 a 1918), Presses Universitaires de Strassbourg, 1997, págs. 151-164.

17. Savigny, F. C., Tratado de la posesión según los principios de Derecho romano, Imprenta de la Sociedad Literaria y Tipográfica, Madrid, 1845, 261 págs. (Biblioteca de Jurisprudencia y Legislación). En la Biblioteca Nacional está catalogada también la edición francesa: Traité de la possession en droit Romain... traduit de l'allemand par Ch. Faivre D’Audelange, Joubert, Librairie de la Cour de Cassation, Paris, 1845, 615 págs.

18. De los diversos materiales reservados para redactar, si la vida alcanza, un Savigny en España, que se pudiera parangonar con el paralelo francés (Motte, O., Savigny et la France, Editions F. Lang, Berne, 1983, 247 págs.), cuento con las abundantes versiones alemanas, francesas e italianas que se encuentran en los catálogos publicados de las bibliotecas del Congreso de Diputados, del Senado. del Consejo de Estado, del antiguo Ministerio de Gracia y Justicia, de la Academia de Ciencias Morales y Políticas, de la Matritense de Jurisprudencia y Legislación, del Ateneo Científico y Literario de Madrid. Son escasas, en cambio, las obras

Doxa. Cuadernos de Filosofía del Derecho, (2020), 43, pp. 31-58 
número de versiones reside, creo, en la evolución experimentada en Madrid en ese final de siglo por las empresas editoriales, dedicadas al libro jurídico. De este tema ya hice un esbozo hace algunos años ${ }^{19}$, del que me serviré y modificaré en lo que atañe a Jhering.

Ya en los años setenta empezó a tomar auge como editora la librería de Victoriano Suárez, que no contaba con imprenta propia, aunque era cliente de una de tipo familiar: sucesivamente: J. M. Pérez, Vda. de J. M. Pérez, Hijos de J. M. Pérez. En ella se habían publicado las primeras obras de los krausistas Francisco Giner ${ }^{20}$ y Gumersindo Azcárate ${ }^{21}$. La obra jurídica editada se incluiría en una Biblioteca de Derecho y Ciencias Sociales.

La conversión de la Imprenta de la Revista de Legislación en editorial se produciría por esos años: en plena expansión empresarial, inauguró la publicación de monografías, bajo la denominación genérica de «bibliotecas», lo que daba un marchamo de continuidad: la Biblioteca jurídica de autores españoles, bajo la dirección de Azcárate desde 1879. Años más tarde y como prueba del auge de las traducciones, el mismo Azcárate dirigiría la Biblioteca jurídica de autores españoles y extranjeros. El nuevo sello editorial evidenciaba el carácter familiar de la empresa: «Hijos de Reus»; finalmente: «Editorial Reus».

En 1891, José Lázaro Galdiano, persona adinerada, con espíritu mercantil y ansia de cultura, venido a Madrid desde Barcelona, y orientado por Emilia Pardo Bazán para que editara en la capital una revista, a la manera de la parisina Revue des deux mondes, puso en marcha La España Moderna ${ }^{22}$. Por las mismas fechas editó, bajo la guía de los krausistas Rafael Altamira y Adolfo G. Posada, respectivamente, dos revistas jurídicas efímeras, que reflejaban el sociologismo reinante en el derecho: La Nueva Ciencia Jurídica y la Revista de Derecho y Sociología. La edición de libros, con el mismo sello que la revista, se inicia en 1891, y amplía sus contenidos, como señala la denominación de la serie: Biblioteca de Jurisprudencia, Filosofía e Historia. Como síntoma, uno de los autores más traducidos fue Herbert Spencer, con seis títulos encargados a Miguel de Unamuno, y otros a Posada, a Pedro Dorado, a José de Caso.

Ya en los primeros años del siglo xx aparece un nuevo editor, Bernardo Rodríguez Serra, que pone en marcha una Biblioteca de Filosofia y Sociología, con mucho menor aliento que las empresas enumeradas, aunque su avidez por incluir en su catálogo a un autor de éxito como Jhering nos obliga a mencionarlo ${ }^{23}$.

de Savigny, editadas en el xIx, existentes en las diez Bibliotecas Universitarias, salvo los casos de la Central y la de Barcelona.

19. Me remito a: El reformismo español, cit., págs. 43-50; 211-219.

20. Principios elementares del Derecho (1871); Estudios filosóficos y religiosos (1876).

21. Estudios económicos y sociales (1877).

22. Aunque la autora, por su especialidad, fija la atención en temas literarios, sigue siendo válida la monografía: Asún Escartín, R., "La editorial 'La España Moderna'», Archivium. Revista de la Facultad de Filología (Málaga) 31-32 (1981-1982) 133-200.

23. No parece que tuviera un orientador. De los apenas diez títulos publicados, a parte del de Jhering, al que luego nos referiremos, solo se destacan dos: uno de Schopenhauer, y otro del jurista socialista Anton Menger (El derecho al producto integro del trabajo). 
Sobre ese cańamazo se tejen, hasta 1933 -fecha que nos aproxima a Ortega -, las traducciones españolas de Jhering, en cuya relación no existe conformidad ${ }^{24}$, si bien coetáneamente se llevó a cabo una completa enumeración de las mismas por Manuel Torres Campos, en 1897, en el segundo tomo de su Bibliografía ${ }^{25}$. Bastará pues completar los datos editoriales y la única traducción, la de Fin, que excede la fecha de ese tomo, para confeccionar una lista fiable, en orden cronológico.

1) La lucha por el derecho. Versión española de Adolfo Posada y Biesca, con un prólogo de D. Leopoldo Alas, J. M. Pérez, Madrid, 1881, LXXI-136 págs. ${ }^{26}$

2) El combate por el derecho, traducido directamente del alemán con la anuencia del autor según la 6. ${ }^{\mathrm{a}}$ edición de la obra por Alfonso de Pando y Gómez, Establecimiento Tipográfico «La Moderna», Madrid, 1882, XIV-84 págs. ${ }^{27}$

3) El espiritu del derecho romano en las distintas fases de su desarrollo, versión española con la autorización del autor y notas por Enrique Príncipe y Satorres, Librería Editorial de don Carlos Bailly-Baillière, 1891, Madrid, Tomo I, XV-414 págs.; Tomo II, 343 págs.; Tomo III, 405 págs.; Tomo IV, 469 págs. ${ }^{28}$

4) Teoria de la posesión. El fundamento de la protección posesoria, versión española con el retrato del autor, aumentada con notas críticas. Estudio preliminar sobre la vida y obras de Ihering por Adolfo Posada, Imprenta de la Revista de Legislación, 1892, XXVII-228 págs.

5) Cuestiones jurídicas. Del interés en los contratos. La posesión: teoría simplificada. Casos jurídicos, traducción de Adolfo Posada, La España Moderna,

24. Me refiero a los elencos incluidos en: Gibert, R., cit. págs. 44-50; Monereo, J.L. «Jhering, ensayo de explicación: introducción a su pensamiento jurídico», estudio preliminar a la reedición de El espiritu del derecho romano, Comares, Granada, 1998, págs. XCI-CXIII; Lloredo Alix, L., «La recepción de Rudolf von Jhering en Europa: un estudio histórico-comparado» Revista telemática de Filosofía del Derecho 17 (2014) 203-250; aquí págs. 243-250.

25. Torres Campos, M., Bibliografía española contemporánea del Derecho y de la Politica, Tomo I. 1800-1880, Fernando Fe, Madrid, 1893, 208 págs./ Tomo II. 1881-1896, Fernando Fe, Madrid, 1897, 165 págs.

26. Como se apuntó antes, la imprenta J.M. Pérez trabajaba para la Librería de Victoriano Suárez. Sobre las circunstancias de traducción y prólogo, mi trabajo: «Leopoldo Alas contra .'Clarín'», Discordia, cit., vol. II, págs. 61 y siguientes. Más concretamente, en pág. 81 y siguiente.

27. Doy noticia en Discordia, cit., I, págs. 79 y siguiente. Hacia 1928, Alfonso Pando y Gómez era magistrado de la Audiencia Territorial de Madrid.

28. Tuvo amplia difusión. He comprobado hasta cinco «tiradas», estando datada la última en 1907. El traductor dedica su trabajo a Germán Gamazo, relevante abogado a la sazón, en cuyo despacho al parecer trabajaba. Aunque no se indica, se considera la traducción hecha sobre la francesa, que siempre a partir de la 3.a alemana, se había editado tres veces: en 1877-1878. 1880 y 1886-1888. Esta última podría ser la base de partida de la versión espańola: L'esprit du droit romain dans les diverses phases de son développement. Traduit de la 3ème édition avez l'autorisation de l'auteur par O. de Meulenaere, Librairie Marescq Ainé, Paris, et F. Clemm, Gand, 1886-1888. Enrique Principe y Satorres, hijo del literato Miguel Agustín Príncipe, además de haber sido redactor del Diario de sesiones del Senado, colaboró en prensa de la época con leves composiciones poéticas. Dieciocho de ellas, dedicadas a acontecimientos de la Familia real, se conservan en la Biblioteca de Palacio (Sig II/3608). Otro de sus poemas es la letra de un histórico vals peruano: Hermelinda/Escucha, amada mía. Necrología: El Liberal (Madrid), 4 de septiembre de 1906, pág. 2. 
Madrid, s. a. [1895], 246 págs. (Biblioteca de Jurisprudencia, Filosofía e Historia $)^{29}$

6) La voluntad en la posesión: con la crica del método jurídico reinante, versión española de Adolfo Posada, Imprenta de la Revista de Legislación, 1896, Madrid, 381 págs. (Biblioteca jurídica de autores españoles y extranjeros) ${ }^{30}$.

7) Prehistoria de los indoeuropeos. Obra póstuma, versión española con un estudio preliminar de Adolfo Posada, Librería de Victoriano Suárez, Madrid, 1896, XXXI-586 págs.

8) El fin en el derecho, traducción de L. Rodríguez, edición de B. Rodríguez Serra, Madrid, 1911 (¿), 354 págs. (Biblioteca de Filosofía y Sociología) ${ }^{31}$.

Durante este proceso de edición, la figura de Jhering es tratada de modo diverso por las tres corrientes de pensamiento jurídico, vigentes en la Restauración: krausismo ${ }^{32}$, neotomismo ${ }^{33}$; escuela histórica catalana ${ }^{34}$. Estamos pues ante un «tópico» de la cultura jurídica del momento, hasta el punto de que sea tema de una tesis doctoral defendida en la Central en julio de $1906^{35}$. En los años siguientes la memoria de Jhering languidece, hasta que reviva, sobre todo en el interés de Ortega y Gasset, tras su retirada política.

29. La España Moderna nunca indicó en sus libros la fecha de edición, lo que ha dado pié a diversas imprecisiones. La investigación, hecha en los archivos y correspondencia mercantil, por J. A. Yeves Andrés, con la colaboración de F. J. Martínez Rodríguez y M. Tostón Olalla, La España Moderna. Catálogo editorial. Índices de la Revista, Libris, Madrid, 2002, 439 págs., resuelve la incertidumbre: en pág. 95, con el número 215, se indica que la obra de Jhering se distribuyó en mayo de 1895.

30. Estos tres títulos sobre la posesión orientan una espléndida monografía de la civilística española: Dalmau y (Marqués) de Olivart, R., La posesión. Apuntes y fragmentos de una nueva teoría posesoria. Imprenta de J. Jepús, Barcelona, 1884. El civilista pasó pronto a dedicarse con buen nivel al derecho internacional. En reciente monografía: De la Rasilla y del Moral, I., In the Shadow of Vitoria. A History of International Law in Spain (1770-1953), Brill/Nijhoff, Leiden/Boston, 2018, pág. 77, nota 253, se menciona una carta de Jhering a Dalmau, fechada el 28 de noviembre de 1884, que bien puede ser un acuse de recibo de la obra de Dalmau.

31. Solo se tradujo el volumen I, de los dos de que consta la obra. Figura sin fecha de edición. El depósito obligatorio en la Biblioteca Nacional de Madrid inclina a preferir la fecha indicada en su catálogo, que es la de 1911, aunque esta mantiene el interrogante. Respecto del traductor, creemos plausible que se trate de Leonardo Rodríguez Díaz (1877-1922), licenciado en derecho por la Universidad de Santiago de Compostela, periodista que hizo crónicas sobre la Guerra europea con tendencia más bien germanófila, y político, que murió inesperadamente en Madrid, siendo ministro en un gobierno Romanones, aunque no se aluda a esa traducción en la fuente que utilizamos: el Diccionario Biográfico Español, de la Real Academia de la Historia (dbe.rah.es/biografías/25744/leonardo-rodríguez-díaz).

32. Además de las introducciones de A. Posada a las obras traducidas, o el prólogo de L. Alas, citaría por su interés: Navarro Flores, M., «Sobre el concepto del derecho según Jhering» RGLJ 98 (1901) 581-590.

33. Rodríguez de Cepeda, R., Exposición y juicio crítico de algunas teorías modernas del derecho. Imprenta de Nicasio Ríus Monfort, Valencia, 1893, 52 págs. Sobre Jhering, centrado en Zweck, págs. 10-26.

34. Carreras Artau, T., «Sobre 'La lucha por el Derecho'», Revista Jurídica de Cataluña 9 (1903) 297-308.

35. Urbano Guerrero, J., El sistema jurídico de Jhering. No pasó de manuscrito. (Cfr. Miguel Alonso, A. (dir.), Doctores en derecho por la Universidad Central. Catálogo de tesis doctorales, Dykinson, Madrid, 2018, pág. 443, n. 2696. José Urbano Guerrero (1883-1946), que además estudió en Heidelberg y París, abrazó en la guerra civil la causa de la República, y ejerció en 1936, en Mahón, de magistrado de espionaje y alta traición. Tras pasar por un campo de concentración francés, pudo trasladarse a Méjico. En la UNAM enseñó economía política (Cfr. Manrique Figueroa, C., «José Urbano Guerrero», en; Serrano Migallón, F. (coord.),

Doxa. Cuadernos de Filosofía del Derecho, (2020), 43, pp. 31-58 


\section{LOS «USOS SOCIALES» EN JHERING}

Esta sucinta crónica de su recepción en España quizás pueda ayudar a resolver la cuestión de por qué entre nosotros pasó la "moda» de traducir y estudiar a Jhering. Ciertamente, la siguiente traducción, y no completa, debida a Román Riaza ${ }^{36}$, data ya de 1933. El traductor constata en su «nota preliminar», que el interés por el jurista germano, «lejos de crecer, puede decirse que ha disminuido», y que a ello "quizás» ha contribuido "la falta de una versión decorosa» de Fin, ya que la que disponemos, además de ser incompleta, «resulta poco recomendable». Pues bien, el que se tradujera solo el primer tomo de la obra no es causa de que se borrara la fama del autor. Las versiones que, fuera de la italiana muy tardía, pudieran haber hallado eco en Espańa, como la francesa o incluso la inglesa', también lo fueron solo del primer tomo y, sin embargo, el influjo de Jhering en Francia se continuó en el sociologisme juridique de François Gény, y en Norteamérica en la sociological jurisprudence de Roscoe Pound, por ejemplo. Y en la cultura jurídica alemana siguió presente en la «escuela de derecho libre» y en la «jurisprudencia de intereses». De todos estos movimientos, en la cultura jurídica española apenas hubo alguna correcta noticia ${ }^{37}$, pero no una recepción. Paradójicamente, lo que se constata es una muy retrasada aceptación de Savigny, que se refleja en la traducción de sus obras básicas y en la adaptación profesoral de la pandectística alemana, que se superpondrá, en sus «tratados», a la sistemática del código civil recién estrenado ${ }^{38}$. Lo cierto es que quien en Espańa reactualiza a Jhering no es un jurista, sino un filósofo y escritor, Ortega y Gasset. No era el primer no jurista que se hacía eco de opiniones del alemán en los años en que se acumulaban las traducciones españolas ${ }^{39}$. Pero Ortega va a ser un tardío editor y sobre todo va a hacer suyas, de manera peculiar, algunas de las tesis de Jhering sobre los «usos sociales», que este aborda con diversa óptica, tanto en Espiritu como en Zweck. A Ortega no le interesa el derecho romano, aunque sí el derecho y Roma, comunes elementos de una experiencia histórica ejemplar. El propio

Los maestros del exilio español en la Facultad de derecho, Porrúa/ Facultad de Derecho de la UNAM, México D.F., 2003, págs. 403 y ss.).

36. Jhering, R. v., Jurisprudencia en broma y en serio, traducción de la tercera edición alemana por R. Riaza, Revista de Derecho Privado, Madrid, 1933, 316 págs. (las citas en páginas 1 y 2).

37. González, J., «La escuela de Tubinga», Revista Crítica de Derecho Inmobiliario XI / 128 (1935) 561-575; Idem, "Jurisprudencia de intereses», Revista Crítica de Derecho Inmobiliario XI /126 (1935) 498-521.

38. Savigny, F. Ch. von, Sistema del derecho romano actual, traducido del alemán por Ch. Guénoux, vertido al castellano por J. Mesía y M. Poley, profesores... de la Institución Libre de Enseñanza, y precedido de un prólogo de M. Durán y Bas, 5 vols, F. Góngora y Cía editores, Madrid, 1878-1879 (Biblioteca Universal. Sección Jurídica); Idem, De la vocación de nuestro siglo para la legislación y para la ciencia del derecho, La Espańa Moderna, Madrid, s.a. [1896] (Biblioteca de jurisprudencia, filosofía e historia) (pról. A. Posada). Sobre el proceso apuntado: Blasco, Y., «Notas sobre la recepción de la parte general de Savigny en España», Cuadernos del Instituto Antonio de Nebrija 2 (1999) 11-36.

39. Por ejemplo: M. de Unamuno, en colaboraciones en el diario La lucha de clases, de Bilbao, del 8 de agosto de 1896 y del 30 de enero de 1897 (cfr. Pérez de la Dehesa, R, Política y sociedad en el primer Unamuno, Ciencia Nueva, Madrid, 1966, págs. 186 y 189); Ganivet, A., Idearium español (1897), Espasa Calpe, Madrid, 1981 (Austral 139), págs. 144 y siguiente, con referencia a Prehistoria de los indoeuropeos. 
Jhering facilita el acceso al derecho de quien no es romanista, y protesta reiteradamente, para prevenirse de las críticas de sus colegas: «Mi atención no se dirige al derecho romano, sino al derecho...; mi tarea es más de índole filosófico-jurídica y dogmática, que de historiador del derecho...» ${ }^{40}$. Con lo que perfilaba lo ya dicho en el prólogo, pero en la primera edición: «...no se trata solo de lo que importa al derecho romano, sino también de lo que con relación al derecho romano y en él constituye sobre todo la esencia (Wesen) del derecho...»" ${ }^{41}$. Así se fija el alcance de la metáfora: «espíritu» (Geist) es lo permanente en una realidad histórica que evoluciona.

La afinidad en el gusto por Roma y su experiencia jurídica une a Ortega con Jhering, a través de la referencia de ambos a Theodor Mommsen. En el español, basta prestar atención al índice de nombres de su obra completa para convencerse de las numerosas citas que de él hace. Como veremos, el tema del poder político en la sociedad, lleva a Ortega al historiador alemán, que, una vez traducido, se había convertido el lugar común de la cultura española ${ }^{42}$. Por su parte Jhering, un año más joven que Mommsen, habla con él a lo largo de sus obras mayores como si fuera un colega con el que se coincide o del que se discrepa ${ }^{43}$. Ambos procedían además de Frisia, y compartían una similar visión viva, dinámica, de la historia romana. Ortega, aunque tiene un alto concepto de uno y otro ${ }^{44}$, achaca a Mommsen que, al redactar esa historia, se haya

40. Geist des römischen Rechts auf den verschiedenen Stufen seiner Entwicklung, Breitkopf und Härtel, Leipzig, Tomo II, Segunda Parte, 2. ${ }^{a}$ ed., 1866, Vorwort, IX. Los diversos tomos, tanto de Geist, como de Zweck, en sus varias ediciones, se imprimieron, en distintas fechas, en la misma editorial y ciudad, por lo que no reiteraremos en adelante esos dos datos. En cuanto a Geist, nos servimos en nuestro trabajo -salvo en la última cita- de la 1. a edición (1852-1865), digitalizada (Deutsche Digitale Bibliothek).

41. Geist, 1.a ed., Tomo II, Segunda Parte, 1858, pág. XII. Más brillante la «divisa» situada por él al frente de la presentación de la revista jurídica, fundada junto con Carl Friedrich Gerber: «Unsere Aufgabe», Jahrbuch des heutigen römischen und deutschen Recht, 1 (1857), p. 52: «... durch das römische Recht über das römische Recht hinaus».

42. «Sobre una nueva interpretación de la histora universal. Exposición y examen de la obra de Arnold Toynbee: «A Study of History" (1948-1949), Obras Completas (en adelante, OC) [2004-2010], Taurus/ Fundación Ortega y Gasset, Madrid, Tomo IX, pág. 1334: «....atenidos solo a lo que Mommsen nos enseńó a considerar como la sustancia misma de la historia romana, a saber: la evolución de su derecho público, de su Estado». Las primeras traducciones de las dos obras de Mommsen citadas por Ortega: Historia de Roma, 9 vols., 1876-1877, Góngora, Madrid (trad. de A. García Moreno; pról. de F. Fernándes y González); Compendio del derecho público romano, La España Moderna, s. a. [1893], Madrid, 635 págs. (traducción de P. Dorado Montero). Con ocasión del centenario de la muerte de Mommsen tenemos más noticias de estas traducciones: Delgado Delgado, J.A., «La obra de Theodor Mommsen en España: la traducción española de la 'Römische Geschichte’ Gerión 21/2 (2003) 45-58; Romero Recio, M., «Traducciones y ediciones de la obra de Mommsen en España (1876-1905)», en: Martínez-Pinna, J. (coord.), En el Centenario de Theodor Mommsen (1817-1903). Homenaje desde la Universidad Española, Universidad de Málaga/Real Academia de la Historia, Málaga/Madrid, 2005, 135-152.

43. Así, como muestra de una y otra actitud, Der Zweck im Recht, Band II, reimpresión de la 4. a edición, (Leipzig 1905), Georg Olms, Hildesheim/ New York, 1970, págs. 344 y 345, en sendas notas. Creo que esta 4. ${ }^{a}$ edición, calificada por el editor como "popular», sería la manejada por Ortega.

44. «Mommsen, uno de los pocos genios que ha habido en la ciencia histórica y al que por mi parte dedico un fervoroso culto...» Si bien, cuando se trata de aclarar el alcance de imperium en el derecho público romano, opina: «...el propio Mommsen tropieza con ello. pero no acierta a darle su sentido eficaz histórico que, en cambio, le da Jhering en su libro Espiritu del Derecho romano, una de las obras... gigantescas del siglo

Doxa. Cuadernos de Filosofía del Derecho, (2020), 43, pp. 31-58 
detenido en el fin de la República y la proclamación de Julio César, y no haya pasado más allá, a ocuparse del Imperio, siendo así que a partir de él y de sus renovaciones se explica Europa, y ello por ser hijo de su época: el xIx fue el siglo del liberalismo y para el liberal Mommsen la libertas romana había concluido con el Imperio ${ }^{45}$. Sin embargo, en la biografía intelectual de Ortega, el conocimiento de Mommsen es de primera hora, y se mantiene hasta el final de sus días. Le citará tempranamente en artículos de prensa, siendo uno de ellos el punto de partida de su discurso sobre el derecho: «Hasta que un día Mommsen tuvo cierta idea feliz: suponer que la historia de Roma había de ser sustancialmente la historia de las variaciones del Derecho romano. Desde entonces hay historia de Roma ${ }^{46}$. Y acude a Mommsen para iniciar los primeros compases de España invertebrada: «La historia de toda nación, y sobre todo de la nación latina, es un vasto sistema de incorporación $»^{47}$. En contraste, a Jhering, como veremos en el siguiente apartado, no se le cita hasta 1939. Es casi un conocido de última hora.

Aun habiendo nacido casi medio siglo después, en el caso de Ortega es sin embargo anterior al de Jhering el conocimiento de Max Weber, «el más grande sociólogo reciente ${ }^{48}$, de quien cita del original sus escritos de sociología de la religión y de sociología y economía. De él publicará un artículo en la Revista de Occidente ${ }^{49}$, del que hará una glosa inmediata: Sobre la muerte de $R o m a^{50}$. Ante todo resaltará que Weber es anterior a la literatura del «decadentismo» vinculada a Spengler: estamos ante una «meditación de las decadencias» de sentido opuesto a la realizada por este. Al tratar de identificar las causas económicas, que anuncian el fin del Imperio romano, parece decisiva la evolución de la esclavitud. Observa Ortega que ese planteamiento no es marxista, ya que ese hecho mostrenco se abordó por Roma desde una perspectiva acorde con su historia: «No es, pues, la intención de Weber decir: porque la economía romana fue tal, Roma sucumbió; sino más bien esto otro: porque Roma fue como fue se desarrolló

pasado que no conocen las nuevas generaciones». (Ambas citas en «Sobre una nueva interpretación», cit. OC, IX, págs. 1247 y 1269).

45. Cfr. «Del Imperio romano» (1941), OC, Tomo VI, págs. 85 y siguiente Es conocido que, por manifestarse crítico con la política universitaria de Bismarck, fue llevado a los tribunales. En su vida ni fue nacionalista en sentido riguroso, ni «romántico», ni antisemita. Véase como marco de referencia: Heuss, A., Theodor Mommsen und das 19. Jahrhundert, Hirt, Kiel, 1956; Whitman, J.Q., The Legacy of Roman Law in the German Romantic Era, Princeton University Press, Princeton, N.J., 1990. Preparando esta nota me llama la atención que al consultar la obra "clásica» de Eric Wolf, Grosse Rechtsdenker in der deutschen Geistesgeschichte, cuyas dos primeras ediciones son de 1939 y 1943, es decir, en plena «era nazi», su copioso índice de "personas» siga sin incluir a Mommsen en la 4. ${ }^{\mathrm{a}}$ ed. (1963).

46. «Nuevo libro de Azorín» El Imparcial (11 de junio de 1912). OC, Tomo I, pág. 537. Repetirá la idea, incluso precisándola, años después (ver nota 40).

47. «España invertebrada», OC, Tomo III, pág. 438.

48. «El hombre y la gente». X. Meditación del saludo, OC, Tomo X, pág. 261. La 1. a edición alemana de Wirtschaft und Gesellschaft es de 1922, y en su primer apartado: "Conceptos sociológicos fundamentales», cita Zweck, II de Jhering. Cfr. Economía y sociedad, Fondo de Cultura Económica, México, 2.a ed. española, 1964, págs. 24 y 27, en relación con los usos sociales (Sitte).

49. «La decadencia de la cultura antigua: sus causas sociales» Revista de Occidente IV/XXXVII (julio 1926) 25-59.

50. «Sobre la muerte de Roma», glosa en la entrega VI (1927) de El espectador, fechada en agosto de 1926. OC Tomo II, pág. 644. 
en ella un proceso económico morboso que acaba estrangulándose a sí mismo». Los «reaccionarios» romanos fueron incapaces de ser «progresistas», no supieron proceder ante los nuevos tiempos con nuevas técnicas jurídicas. Ese diagnóstico difícilmente lo admitirían ni Jhering ${ }^{51}$, ni Mommsen ${ }^{52}$. Por lo demás, parece plausible que fue la lectura de Weber la que llevó a Ortega al conocimiento de Jhering.

Pero Jhering se pone a tiro de Ortega, cuando este lleva un puñado de años merodeando una tarea que, una vez abandonada la política, llena su tiempo: construir una teoría de la sociedad, quizá en la línea de la sociología "comprensiva», y vinculada al proceso histórico, tal como la plantea Weber, pero sin aceptar su punto de partida: la bilateral «acción social» (soziales Handeln) ${ }^{53}$, que relega ante el deslumbramiento que le produce la omnipresencia anónima de los «usos sociales». Una de las tempranas formulaciones de la tesis orteguiana queda fijada en torno a 1939: «Pero con todo eso desembocamos en algo muy importante, a saber, que si ante los usos nos comportamos dócilmente, sin pretender eludirlos de frente y, por tanto, en forma automática por darnos cuenta del enorme poder que la sociedad usufructúa, el nombre exacto de ese sometimiento no es otro que "obediencia". Obedecemos a los usos, y esto quiere decir que los usos son órdenes, imperaciones ${ }^{54}$. Y en esos dos puntos -omnipresencia de los usos y su carácter «imperante»- acude Jhering en su apoyo ${ }^{55}$. Un apoyo selectivo y tan discontinuo como fue el modo de redactar este sus obras, perdiéndose en continuas digresiones, en las que el jurista alemán se recreaba hasta tal punto que sus dos obras de mayor fuste quedaron incompletas ${ }^{56}$.

51. Geist, 1.a ed., Tomo II, Segunda Parte, 1858. sienta que: la «innere Erweiterung» posibilitada por el «naturhistorische Methode» permitió a la «jurisprudencia constructiva» evolucionar como «jurisprudencia creativa» (págs. 379 y 384 y siguientes).

52. Frente a lo afirmado por Ortega, Mommsen estudió y publicó sobre el Imperio romano: Die Provinzen von Caesar bis Diocletian, Weidmann, Berlin, 1885, considerado por el editor 5. ${ }^{\circ}$ tomo de la Römische Geschichte. Fue traducido al español por W. Roces: El mundo de los Césares, Fondo de Cultura Económica, México, 1945, 766 págs.

53. Cfr. Economía y sociedad, cit., págs. 18-45.

54. Ortega y Gasset, J., El hombre y la gente [Curso 1939-1940], iniciado hacia el 4 de octubre de 1939 en Buenos Aires. OC, Tomo IX, pág. 410.

55. Sobre los «usos sociales» en Jhering: González Vicén, F., «Los usos sociales. Un ensayo de sociología descriptiva», Anuario de Filosofía del Derecho 8 (1991) 481-493, principalmente págs. 483-486, 489.

56. Parece anecdótico, pero estamos ante un criterio interpretativo relevante. He aquí lo que nos dice Jhering de cómo procedía en la redacción: «Mi trabajo daba vueltas y vueltas, sin moverse de sitio, y me habría visto condenado toda mi vida si hubiera tenido que esperar a que mi obra recibiera mi propio aplauso; mi autocrítica se había desgastado tanto que en muchas de las modificaciones hechas apenas sabía si la mejoraba o la empeoraba; aquel movimiento en círculo, si se me permite decirlo, me desesperaba moralmente. Sentí finalmente que debía poner fin a la situación, y llamé en mi ayuda a mi impresor. Pensé que los libros no venían a este mundo en un solo intento, sino que más bien eran compuestos e impresos folio a folio, y que bien pueden los primeros folios ver la luz del mundo, mientras los siguientes se encuentran en estado embrionario. Así puse el pasado mayo en manos del cajista un menguado manuscrito, para que lo fuera componiendo, privándome yo de devolverlo corregido folio a folio -el folio, una vez impreso, lo respeto como fait accompli-y obligándome a seguir escribiendo folio a folio" (Geist, 1. ${ }^{\mathrm{a}}$ ed., Tomo I (1858), Vorrede, págs. VI-VII. El prólogo tiene fecha de 29 de abril de 1852) La traducción es mía.

Doxa. Cuadernos de Filosofía del Derecho, (2020), 43, pp. 31-58 
Vamos, pues, a prestar atención a pasajes que contienen puntos de vista de Jhering comentados por Ortega: algunos contenidos en Geist, y otros procedentes del tomo II de Zweck.

Respecto de los primeros, me fijaré en tres puntos:

1. $\left.{ }^{\circ}\right)$ Vinculación del derecho con el entorno social e histórico. «No podríamos determinar el espíritu del derecho romano sin vincularlo al espíritu del pueblo y de la época, ni permitirnos un juicio sobre el mismo sin tener en cuenta la situación real de la vida, la realidad del derecho». Pero no se crea que ello equivalga a redactar una historia del organismo jurídico romano, distinto en las diversas etapas de su desarrollo histórico. Si se pone el acento en lo "psíquico», es porque no se trata de dar con un sistema lógico, con una teoría, ya que el «espíritu» ha de vincularse a la realidad material: las proposiciones jurídicas -la formulación del derecho en cualquiera de sus manifestaciones- tienen que ver con «los fines y necesidades de un tiempo determinado, y en ellos reside que se estructuren de una u otra forma ${ }^{57}$.

2. ${ }^{\circ}$ ) Diverso modo de ejercer el imperium en la Monarquía y en la República, en razón de los «usos vigentes» en una y otra época. Roma tuvo que abrirse paso entre sus vecinos mediante la fuerza. De sus tres principios organizativos -familiar, sacerdotal y militar-, el monarca asumía el militar no de modo puntual, sino permanente: el pueblo se articulaba en unidades militares, los sacerdotes escrutaban los auspicios antes del combate, y el monarca no era el patriarca de patriarcas: cada gens regía el ámbito privado. En ese contexto, «el imperium se puede reconducir a un contrato, pero solo en lo que respecta a su otorgamiento. Su duración y su ejercicio en cada caso no depende ya del consentimiento del pueblo: su modo de otorgarse confiere una relación de duradero sometimiento $"{ }^{58}$. Pero como la confianza en una persona ha llevado al contrato tácito, la quiebra de tal confianza conduce a la extinción, inmediata o paulatina, de ese contrato.

En la República, el imperium se ejerce por las distintas magistraturas -magistri (superiores), no ministri (servidores, inferiores)- con un poder limitado en el tiempo, pero absoluto en su mandato, aunque esas magistraturas pudieran ser llamadas a responder de su mandato, una vez que el régimen, inicialmente de patricios, haya dado entrada, no sin tensiones, a la plebs $^{59}$. Pero hay que preguntarse si esa estructura de derecho público (Senatus Populusque Romanus) fue capaz por sí sola de garantizar la libertas. La praxis del, por lo demás, escaso derecho público romano, se remitía al derecho consuetudinario, asentado en una fuente anterior: los usos (Sitte), las tradiciones (mos, mores maiorum). «Pues al derecho consuetudinario antecede un estado de indeterminación, que he denominado "uso" (Sitte). El uso es respecto del derecho consuetudinario cosa imperfecta, pero esta imperfección es una ventaja. Para ciertas relaciones solo es posible el uso: este, en cuanto fase previa, dice hasta dónde la regla debe ser observada

57. Geist, I, págs 50 (la primera cita) y 41 (la segunda). Lo subrayado y entrecomillado es del autor. La traducción de los textos originales seguirá siendo nuestra.

58. Geist, I, pág. 249.

59. Cfr. Geist, 1. ${ }^{a}$ ed., II, Parte Primera (1854), págs, 267-320. 
en general, pero permite una desviación en casos motivados, que el derecho consuetudinario no consiente» ${ }^{60}$. El uso flexibiliza la ley y la costumbre jurídicas.

$\left.3 .^{\circ}\right)$ El carácter formalista del derecho. Aunque del derecho romano arcaico procedieran buena parte de los signos, símbolos y palabras que acompañaban los actos sociales de alcance jurídico, ese formalismo, simplificado a lo largo del tiempo, no deja de ser un producto artístico del espíritu jurídico. Las diversas partes del cuerpo se han prestado a muchos símbolos, pero de forma principal, la mano. «Tender la mano al enemigo es muestra de indefensión y de actitud de perdón, estrecharse las manos es prenda de fidelidad, se implora a los dioses elevándolas hacia el cielo, los esposos unen sus manos, alzar la mano es muestra disponibilidad. En derecho privado, asir y tomar son las funciones más importantes de la mano" ${ }^{61}$. Por supuesto buena parte de esos gestos fueron usos, que el derecho formalista hizo suyos. Pero la mano acompaña a la palabra, que en determinados actos ha de decirse de viva voz. Mas no «al modo como en la vida ordinaria se acompańan las palabras con una pantomima de la mano, si bien en los actos jurídicos también la palabra secunda la acción e incluso puede el peso cargar sobre la acción, siendo las palabras su explicación o constatación. Pero los hechos que se quiere evidenciar han de expresarse por medio de palabras». Dos usos -gesto y lenguaje- están pues íntimamente vinculados, aunque el uno ha surgido espontáneamente de la vida. Mientras que el segundo ha sido elaborado por la jurisprudencia.

Respecto de los puntos de vista de Zweck, que interesaron a Ortega, se contienen en el volumen II, aunque este no se cuestionara por qué Jhering suspende la redacción de Geist, al considerar manca la provisional relación establecida entre voluntad e interés ${ }^{62}$, lo que le impulsa a emprender la redacción de una nueva obra dedicada íntegramente a poner en pie una teoría finalista del derecho ${ }^{63}$, que Ortega pasa por alto, quizá por su tono utilitarista, que parte del egoísmo individual, para derivar al fin hacia un eudemonismo social. El volumen I (1877) construye como complemento necesario una «mecánica social», que domestique los egoísmos enfrentados mediante distintos instrumentos, coronados por la fuerza organizada -es decir, sometida al derecho- del Estado. Esas tesis se desarrollan en los capítulos I a VIII, de ese volumen.

Propósito del autor era explicar, en razón asimismo de sus fines, otro orden de conducta humana, la moral, para dar razón de actitudes como la abnegación o la benevolencia. A la moral pensaba dedicar el capítulo IX, lo que ciertamente no ocurrió. Pues si bien es cierto que el volumen II, en las dos primeras ediciones (1883 y 1886), se abre con un capítulo IX, dedicado a Die Ethik, prontamente se desvía por

60. Ibidem, pág. 284.

61. Geist, 1. a ed., II, Parte Segunda (1858), pág. 595. La cita siguiente en pág. 590.

62. Geist, 1. a ed. III, Parte Primera (1865), «Insuficiencia de las ideas de voluntad y de fuerza para definir el derecho. El momento sustancial de la idea del derecho e ideas que de él dimanan: utilidad, bien, valor, interés» (págs. 307-327).

63. Esta es la divisa con que se abre el tomo I, en la edición indicada más arriba (véase nota 41): «Der Zweck ist der Schöpfer des ganzen Rechts» («El fin es el creador de todo el derecho»). 
otros derroteros ${ }^{64}$. El «método etimológico», tan querido por él, le lleva a ampliar el binomio «derecho-moral») con un tercer elemento: de origen romano es la distinción justum-bonum (derecho-moral); de origen germánico, la establecida entre justum-decorum (Sitte) (derecho-usos sociales) ${ }^{65}$. Pero más allá de hurgar en las raíces linguísticas, quizá Jhering recordara que la tríada (bonum-justum-decorum) se había consolidado en el "derecho natural racionalista», siendo Christian Thomasius (1655-1728), a quien Jhering cita alguna vez, su clásico expositor ${ }^{66}$. Tanto Thomasius como Jhering se dedicaron, cada uno en su tiempo, a analizar el ámbito de los «usos», la "cortesía», las «maneras», la «etiqueta». En el caso de Jhering, de modo excesivo: un volumen de casi seiscientas páginas e incompleto, y escrito al precio de no concluir la obra. Pero Ortega sacó acicates para su empresa, sobre todo de la parte dedicada a las «simbólicas»: la del «gesto humano» $\mathrm{y}$ «la del lenguaje oral ${ }^{67}$.

\section{LOS «USOS SOCIALES» EN ORTEGA Y GASSET}

Entre nosotros, quienes en torno a 1960 abordaron el tema del derecho en Ortega, apenas mencionaron a Jhering ${ }^{68}$, a pesar de que a los dos ańos de la muerte de aquel se publicara El hombre y la gente (1957), fuente ineludible para su propósito, en la que ya se cita a Jhering. Fuente, sin embargo, decepcionante, por quedar sin desarrollo bastantes de los temas que se encadenaban e incluso se programaban hipotéticamente. Parece como si un mismo destino -la obra incompleta- fuera compartido por ambos.

64. No es fácil reconstruir el esquema de Zweck. Plausible es el trazado en la versión italiana, realizada hace tiempo, por M. G. Losano (Lo scopo nel diritto, Einaudi, Milano, 1972), contenido en su Introduzione (págs. LV-LIX), así como el Indice analitico (págs. 401-409) referido solo al volumen I, el único traducido. Una nueva edición, sin número de orden (Nino Aragno Editore, Milano, 2014) presenta una nueva introducción y prescinde del índice analítico.

65. Zweck, II, págs 9-11. En la edición 4.a , que es la citada, el capítulo IX se titula: Das Sittliche («usos sociales», «normas (no jurídicas) de convivencia»). Si tradujéramos Siitlichkeit por «eticidad», tendríamos que precisar que no estamos ante el término tal como lo entendió Hegel.

66. Cfr. Geist, II, Parte Segunda, pág. VI. Sobre el autor «ilustrado», remito a mi trabajo: «Christian Thomasius, el impertinente», en Discordia, vol. I, cit.. págs. 203-227.

67. Cfr. Zweck, II, págs. 505 y siguientes.

68. En orden cronológico: Legaz Lacambra, L., «El derecho internacional en el pensamiento de José Ortega y Gasset» Revista de Estudios Políticos 111 (1960) 5-42; Hierro S.-Pescador, J. El derecho en Ortega, Ediciones de la Revista de Occidente, Madrid, 1965, 345 págs.; Elías de Tejada, F., «El concepto del derecho de José Ortega y Gasset» Anuario de Filosofía del Derecho 12 (1966) 37-52; Idem, «Derecho y ley en José Ortega y Gasset» Anales de la Cátedra Francisco Suárez, 5-6 (1965-1966) 109-127; Idem, "Ortega y Gasset ante la filosofía del derecho", en: Homenaje al Profesor Giménez Fernández, Universidad, Sevilla, vol. I, 1967, 373389. Solo el libro de Hierro S.-Pescador cita una vez a Jhering, en pág. 247. Esa casi ausencia se subsana por Gibert, R., "Jhering en España» (1970), citado más arriba (nota 4), que dedica a Ortega las págs. 62-64. Poco después del estudio de Legaz se escribió una selección de frases de Ortega, ordenadas por temas, y que en un apéndice se propone «rectificar» a Ortega - «falangismo orteguiano»-con afirmaciones de José Antonio Primo de Rivera y Francisco Franco (López Medel, J., Ortega en el pensamiento jurídico contemporáneo, Secretaría General del Movimiento, Madrid, 1960, 147 págs. (en págs. 128-129, cita de Franco; en pág. 130, cita de Primo de Rivera). 
El libro póstumo El hombre y la gente tiene una génesis, que arranca -el dato es relevante- en 1934. Dada esa lenta gestación, será preciso aludir a otros trabajos de Ortega aparecidos en ese tiempo en el que iba tomando cuerpo el tema de los «usos sociales», como hecho central de su «sociología». Como esa cuestión la abordó Ortega antes del "gozoso descubrimiento» de las dos obras de Jhering, el proceso apuntado encierra una cierta complejidad.

Antes de todo, se podría decir que el libro, cuando se anuncia por vez primera en Historia como sistema, estudio este publicado inicialmente en inglés en 1935, y en espańol en $1941^{69}$, evidencia que en Ortega hay ya una concepción de lo social, que antecede al conocimiento constatable de Jhering. "A este carácter de la fe social doy el nombre de vigencia. Se dice de una ley que es vigente cuando sus efectos no dependen de que yo la reconozca, sino que actúa y opera prescindiendo de mi adhesión». Y antes de la ley, en su génesis, están los usos sociales: «La sociedad consiste primariamente en un repertorio de usos intelectuales, morales, políticos, técnicos, de juego o placer». Y para que sean una "vigencia social», una "creencia social», necesitan tiempo. En un trabajo publicado en castellano junto con el anterior, Del imperio romano, como extrema forma de uso social, se habla del Estado: «El Estado es solo una de esas presiones sociales, la más fuerte, la comprensión máxima ${ }^{70}$.

Pasemos ya a reconstruir la genealogía de El hombre y la gente. Como punto de partida digamos que, con el título del libro, el autor fue dando en distintos momentos conferencias y cursos. El contenido se iba engrosando, pero el título -lo dijimos- ya estaba fijado desde un primer momento. Sigamos el proceso.

1) La primera conferencia con ese título se pronuncia en Valladolid, en el teatro Pradera, hacia el 20 de mayo de $1934^{71}$, en el marco de actividades de extensión universitaria. En ella, y acorde con la estrategia retórica propia del conferenciante, pretende desde el inicio dejar al auditorio «estupefacto", al mostrarle que lo obvio es más bien problemático. "Todo lo colectivo y social es, pues, lo humano desindividualizado, despersonalizado e irresponsabilizado. Esto es, por un lado, terrible, pues significa que la sociedad, eso en cuyo nombre se exigen hoy tantas cosas, es vida humana deshumanizada... Por eso hallamos todo lo social fuera de nosotros como las piedras y los árboles». Cuando quiere describir la sociedad como "lo humano transformado en naturaleza», enumera algunos de sus ingredientes: «Por otra parte, la opinión pública, los usos, las leyes tienen efectivamente una ventaja: la sociedad conserva el resultado de muchas creaciones individuales, las acumula y transmite». Encontramos ya una mención de los usos y de su función social.

69. Historia como sistema, OC, VI, pág. 70, nota 1 . Las dos citas en págs. 52 y 69, respectivamente.

70. Del Imperio romano, OC, VI, pág. 116.

71. OC, IX, págs. 166-174. Las citas en págs. 173 y 174. En la nota editorial de esta edición de OC, págs. 1432 y siguientes., se remite a la inclusión de esta conferencia en: Universidad de Madrid. Facultad de Filosofía y Letras. Año académico de 1934-35, Impr. de Galo Sáez, Madrid, 1934, pág. 35. 
2) El tema se prosigue en la conferencia pronunciada en Rotterdam hacia el 2 de mayo de 1936, siempre con el mismo título ${ }^{72}$. Aquí parte de una pregunta apremiante, dirigida a los sociólogos. «Si apremiamos a estos para que nos digan con precisión y sin evasivas qué entienden por sociedad, por colectividad, los hallaremos divididos en dos bandos: uno de ellos sostiene que lo social se resuelve íntegramente en las relaciones de convivencia entre individuos. Por ejemplo Max Weber -quien llama soziales Handeln a lo que un hombre hace orientándose en el comportamiento real o posible de otro hombre. El bando puesto, cuyo mayor capitán es Hegel, nos dirá que lo social es una realidad diferente de los individuos y que consiste en una conciencia o espíritu distinto del que cada hombre posee. La doctrina es sobremanera turbadora». Rechazadas ambas alternativas, señala su propia opción: «A mi juicio, todos los hechos verdaderamente sociales son formas diversas de un fenómeno prototípico que es el uso. Cuando se ha visto bien el carácter que tiene esa realidad llamada uso se nos impone contra una noción de lo social nueva y sorprendente. Uso es, por ejemplo, el saludo». El hecho crucial del uso y del saludo como prototipo del uso, quedan establecidos a partir de esta afirmación.

3) En el curso 1939-1940, siempre con el mismo título, iniciado hacia el 4 de octubre de 1939, y desarrollado en Buenos Aires, en la sociedad de Amigos del Arte $^{73}$, se ahonda en el tema, dándole unas dimensiones -10 capítulos- que configuran el torso de lo que será la obra en su estadio más avanzado. Para evitar reiteraciones, solo voy a señalar aquellos puntos que suponen una novedad respecto a lo hasta ahora apuntado. Lo primero a subrayar es que, al abordar el tema del saludo, cita el «libro genial de Jhering El fin en el derecho»" ${ }^{74}$, como una de las pocas aportaciones al tema del saludo, así como reitera la crítica al «gran Max Weber» por identificar los «social» con lo «interindividual», con lo que «se ciega en absoluto para ver la extraña, peculiarísima realidad social» ${ }^{75}$. También formula otra tesis sobre el uso: «Mi tesis es, pues, taxativamente esta: el hecho social es ante todo, el uso y todo uso es un caso particular del fenómeno general humano que llamamos "mando y obediencia". El derecho es solo una especie determinada del mandar y obedecer ${ }^{76}$.

4) Por último, el curso 1949-1950, impartido desde el 23 de noviembre de 1949, en el cine Barceló de Madrid, dentro del programa del Instituto de

72. OC, IX, págs. 203-217. Las citas en págs. 214 y 215.

73. OC, IX, págs. 279-437.

74. OC, IX. pág. 320.

75. OC, IX, pág. 375. Este juicio sobre Max Weber lo repite Ortega con frecuencia, a fin de resaltar su propia «originalidad». Cfr., por ejemplo, en el Curso El hombre y la gente de 1949-50 del Instituto de Humanides OC, X, págs. 209, 261, 270; también en la conferencia: El fondo social del «management» europeo, conferencia del 22 de diciembre de 1954 en Torkay (UK): «...el más eminente de los sociólogos alemanes que murió en 1920, Max Weber» comete el error apuntado (Ibidem, pág. 446). El mismo error, según Ortega, lo cometen asimismo Durkheim y Bergson.

76. $O C$, IX, pág. 411. 
Humanidades ${ }^{77}$, que con sus doce apartados, constituye el grueso del volumen póstumo: El hombre y la gente, Revista de Occidente, Madrid, 1957.

En el curso anterior (1948-1949) del Instituto de Humanidades, Ortega desarrolló doce lecciones sobre un libro de Arnold Toynbee ( $A$ Study of History), que había alcanzado amplia difusión entre el "gran público»" ${ }^{78}$. Según Ortega, al llegar al punto de fijar el sentido histórico del imperium del magistrado romano, no aciertan ni Toynbee, ni siquiera Mommsen pero sí Jhering, "en su libro Espíritu del derecho romano, una de las obras gigantescas del siglo pasado que no conocen las nuevas generaciones. Por ser obra enorme, de cinco tomos, que no se encuentra en el mercado, ni en la lengua original ni en la traducción, ello me ha dado ocasión para pedir a un gran amigo mío, don Fernando Vela, que haga una exquisita abreviatura, porque tenía interés en que las nuevas generaciones tomasen contacto con obra de tan profunda ciencia histórica, de tan auténtico sentido histórico»" ${ }^{79}$.

Descritos esos varios encuentros puntuales de Ortega con Jhering, vamos a proceder en lo que sigue, a enumerar los planteamientos de Ortega sobre el derecho que revelan un influjo, de mayor o menor relieve, del jurista alemán en ellos.

En primer lugar: "la realidad derecho» no consiste en las solas prescripciones. Y por eso "tenía razón que le sobraba Savigny» cuando afirmaba -y Ortega hace la cita, tomada De la vocación de nuestro tiempo, en el alemán original- que «el derecho no tiene una existencia en sí, sino que es más bien la misma vida del hombre, desde un aspecto específico». Si bien, ese punto de vista tan válido se oscurece en la escuela histórica por la «nebulosa noción de Volkgeist». El derecho, en cuanto «realidad efectiva y completa..., se apoya en una porción de vigencias sociales que la ley da por supuestas». En este punto, da la «ultima palabra» a Jhering, para quien el derecho romano había consistido, casi íntegramente, en esa forma no estatutaria del derecho. Con metáfora

77. OC, X, págs 139-326. El tema sigue vivo en conferencias dadas en Alemania (Hamburgo y Munich) en 1953, así como en Suiza.

78. Sobre una nueva interpretación de la historia universal. Exposición y examen de la obra de Arnold Toynbee: 'A Study of History', OC, IX, págs. 1185-1408.

79. OC, IX, pág. 1269. Se trata de: Abreviatura de 'El espiritu del derecho romano', Revista de Occidente Argentina, Buenos Aires, 1947, 449 págs. Tiene un prólogo, que firman «Los editores», y que se incluye en la edición de las obras completas que venimos utilizando, por lo que se considera que su autoría ha de atribuirse a Ortega (OC, VI, 363-365) El texto distingue a Jhering de la «escuela histórica» por abordar el derecho romano en su interno dinamismo, en su funcionamiento. Pero para dar con una teoría general del derecho, había que elaborar una sociología. una teoría general de la sociedad, Eso representa El fin en el derecho, «el libro sociológico, tal vez más hondo y sistemático que poseemos». Hay algo de hiperbólico en Ortega: Espiritu no tuvo en alemán ni en traducciones, cinco tomos, sino cuatro como máximo; ni hay tal sistemática en Fin. La traducción no indica la edición alemana de partida, pero es propiamente una abreviatura que conserva buena parte del texto original, una vez que ha prescindido de las numerosas notas. Por el mismo editor y por el mismo traductor e inteligente «abreviador», aparecieron otras tres «abreviaturas», curiosamente sobre autores glosados por Ortega en esas fechas de elaboración de El hombre y la gente: La evolución creadora, de $\mathrm{H}$. Bergson (1947); Principios de Sociología, de H. Spencer (1947); Investigaciones lógicas, de E. Husserl.(1949). Sobre el artífice de esta empresa: Neila, M., «Fernando Vela, la música callada de la traducción» Cuadernos Hispanoamericanos 732 (2011), págs. 91-122.

Doxa. Cuadernos de Filosofía del Derecho, (2020), 43, pp. 31-58 
orteguiana: «Los términos expresos de una ley son como una isla a la vista cuya realidad completa es la ingente montańa submarina de que ella es cima y que no vemos». Más preciso, acuñando una categoría filosófica: el estudio de cualquier institución jurídica, «nos exhumaría los complementos jurídicos no establecidos pero vigentes, sin los cuales aquella ni hubiera existido ni tendría significación inteligible» ${ }^{80}$. La propuesta parece una proyección de la razón vital en el derecho.

En segundo lugar, este discurso sobre el derecho no se entiende si no se vincula a una determinada circunstancia histórica: «...todas la leyes civiles y públicas del Derecho romano dan por supuesta esta «ley» nunca formalmente sancionada, prescrita ni enunciada: «Es obligatorio para todo ciudadano romano comportarse de modo que Roma pueda subsistir». Sería un error suponer que esta perogrullada, por ser, en efecto perogrullada, no expresa una maciza realidad, y otro error suponer que esa vigencia jurídica ha existido mutatis mutandis en todos los países y Estados» ${ }^{81}$. Esa observación ya la había hecho Ortega, con una cierta pomposidad, diseñando una "teoría de los complementos de la vida colectiva» que, a poco de ser incoada, concluye en puntos suspensivos ${ }^{82}$. Procediendo a una narración rauda de la historia de la República romana, llega a la conclusión de que, si para la «razón pura» es «opaco» el equilibrio entre el senado y el tribunado de la plebe, este se hace "transparente» para una razón narrativa, como lo es la «razón histórica». La institución del tribunado vivió «de algo que estaba fuera de ella y del Estado, de un complemento existente en los senos profundos y ultrajurídicos de la Sociedad- en suma, la ley, una vez más, vivió de las costumbres». Partir de estas «es uno de los grandes principios sociológicos», en el que reposó la investigación de Ortega sobre la sociedad, gracias a las virtualidades de la razón histórica ${ }^{83}$. Aunque solo podemos mencionar el tema, esa dimensión de la razón es capaz de abordar asimismo el problema de lo justo, sin acudir, como hizo Jhering, al utilitarismo social; ni tampoco invocando la abstracta y glorificada justicia, «una maza extrajurídica..., que cree torpemente que el derecho es derecho porque es justo, mientras que el romano castizo pensaba inversamente, que lo justo es justo porque es derecho»» ${ }^{84}$. Eso supone, por lo menos, una vida pública con instituciones.

80. Todo lo textual es cita de la conferencia de Berlín (5 de septiembre de 1949), pronunciada en la Freie Universität: De Europa meditatio quaedam, en: OC, X, págs. 320 y 321, incluida la nota a pie de texto.

81. Citado en el mismo lugar, en pág. 321. La simbiosis, correlato de los usos, entre derecho e idiosincrasia de un país conformada por el decurso histórico la considera paradigmática, además de en Roma, en Gran Bretańa, como también lo apreciaba así Jhering (Abreviatura de 'El espíritu del Derecho romano', cit., pág. 213: «Como en la actual Inglaterra, en el espíritu conservador romano tenían gran influencia los usos, los precedentes (exempla majorum) que constituían una práctica».

82. Del Imperio romano, cit, OC, VI, págs. 130 y siguientes. La cita, en pág. 132. Afirmaciones como estas no solo se apoyan en Jhering, sino en la lectura que Ortega hace de Hegel. Remito a: Pérez-Luño, A.-E., «Hegel y Ortega. Meditación sobre los presupuestos historiográficos de la Filosofía del derecho», en Meditaciones sobre Ortega y Gasset, cit., págs. 523-568.

83. Ortega dedicó a la «razón histórica» dos cursos (1940 y 1944) y redactó en 1946 un prólogo a W. Dilthey, Introducción a las ciencias del espiritu (cfr. OC, IX, págs. 477 y siguientes; 625 y siguientes; 723 y siguientes, respectivamente).

84. Del Imperio romano, cit., OC, VI, pág. 107. 
En tercer lugar vamos a abordar esos hechos en que consiste la sociedad: los usos. Se recordará que, en Geist, Jhering se centra en los dos usos sociales que en Roma tienen alcance específico en el derecho formulario: el saludo (mano) y la palabra (lengua). En contraste, el tomo II de Zweck es una prolija descripción y sistematización de múltiples usos. Ortega aborda tan solo los dos usos aludidos en Geist $t^{85}$, aunque Zweck le descubra la dimensión sociológica del tema. Pero además Ortega, con su distinción en «usos débiles» $\mathrm{y}$ «usos fuertes» permite una ósmosis entre unos y otros, de manera que desde los primeros se pueda acceder, con el tiempo, a los segundos: derecho, poder político, Estado. En Jhering, como ya se señaló, hay tres órdenes estancos (Recht, Sitte, Moral), cada uno con sus propias notas distintivas. Siempre contrastando, nos parece que mientras el II tomo de Zweck es obra de una pieza, El hombre y la gente es obra de dos: los ocho primeros capítulos son de corte filosófico, y muestra de ello es que el autor más citado en ellos -en más de una docena de ocasiones- es el Edmund Husserl de Investigaciones lógicas. En contraste, los cuatro últimos (dos dedicados al saludo y otros dos al «decir de la gente»), establecen relación con los «sociólogos» ya conocidos. Del saludo, Ortega señala sus características: a) es un acto que ejecuto yo, pero que no reside ni en mi inteligencia, ni en mi voluntad; esa ejecución depende de la presión de la gente, y así me veo forzado a hacerlo; b) que es un acto que no entiendo, salvo que me conforme diciendo que es un hábito social, algo acostumbrado, frecuente, cuyo significado me transciende. Pero ese acto -el saludo- hubo un tiempo en que sí tuvo sentido. Al querer encontrarlo, Ortega se siente desasistido: a parte de un par de enciclopedias, británica la una, americana la segunda, acude como ya dijimos al Jhering de Fin, pero sobre todo, aunque sea para tomar distancia, a Herbert Spencer, una "momia» a la que desprecia en otros momentos: «Pues bien, entre todo ello lo único que sobre el tema se ha dicho de ingenioso y que, con una ligera variación de la prueba, podría valer como verdadero, es lo que al desgaire nos comunica Spencer y, no sé por qué, no he visto nunca atendido » ${ }^{86}$. Spencer considera nuestro apretón de manos un gesto de sumisión del inferior hacia el superior. El sometido, hecho después esclavo, cae en tierra tendiéndose en el suelo; posteriormente se pone a cuatro patas; más tarde de rodillas; luego pone sus manos en las manos del señor: está en sus manos. Pero siguiendo con su evolución -es el tributo de Spencer a Darwin- el inferior, puesto ya en pie, toma la mano del superior y la besa; si el superior se resiste, se vuelve a insistir, hasta llegar al apretón de manos. La explicación para Ortega «está muy cerca de ser verdadera». En este punto, pues, olvida a Jhering quien vincula el saludo a la paz: ante el desconocido encontradizo, estrechar las manos da a entender que estamos desarmados, que venimos en son de paz. Por último, respecto del segundo paradigma de «uso», la «lengua», el «decir de la gente», los dos capítulos se dilatan ambiciosamente en sentar bases sobre

85. Sin embargo, alguna vez alude con tino a otros usos, como la cortesía, o la moda masculina y femenina, o el traje regional, ya sea de lagarterana o la bata de faralaes.

86. El hombre y la gente [Curso 1949-1950], OC, X, cap X, pág. 273. En la edición de Abreviatura de Principios de Sociología, citada más arriba, en nota 76, los «saludos» son tratados en págs. 267 y siguientes. 
una «nueva filología», o aventurar hipótesis sobre el «origen de las lenguas». Para nuestro propósito nos basta reseñar la reiteración de la misma dinámica: «La lengua es un uso social que viene a interponerse entre los dos, entre la dos intimidades, y cuyo ejercicio o empleo por los individuos es predominantemente irracional»; como, antes de toda reflexión, es irracional el saludo. Y en ambos casos estamos ante un «uso débil». Con la lengua nos «encontramos»: la "lengua materna» nos socializa, si es que queremos entendernos. Pero aunque está «hecha», siempre está «haciéndose». Y es que una cosa es «hablar» y otra "decir»: «El decir, esto es, el anhelo de expresar, manifestar, declarar, es pues una función o actividad anterior al hablar y a la existencia de una lengua tal y como esta ya existe ahí». Soslayemos el tema del origen del lenguaje, aunque para Ortega su gestación es similar a la de cualquier otro «uso»: «Todas las palabras y giros fueron inicialmente inventos individuales que luego se degradaron en usos mecanizados, y entonces, solo entonces, entraron a formar parte de la lengua». En ese uso, a la palabra acompańa la "gesticulación»: «También aquí el individuo se siente presionado por lo que se hace en su contorno; también aquí hay vigencias, y si se hubiera hecho la historia de la gesticulación aparecería bien claro que el uso y el desuso y el abuso de los gestos obedecen a las leyes generales del uso» ${ }^{87}$. A través del lenguaje se va configurando la «opinión pública», preñada de «tópicos». Pero este «uso» se aproxima a un «uso fuerte».

Por último, en cuarto lugar, vamos a intentar poner al descubierto que en Ortega se reitera una actitud crítica frente a la filosofía y los filósofos del derecho, contrapuesta a una apreciación positiva de la sociología. Pero, ¿que entiende por «filósofos del derecho» y por "sociología»? La manzana de la discordia queda identificada en la distinción entre «usos débiles» $\mathrm{y}$ "usos fuertes», que incluye entre los segundos el «derecho». No reconocer esto, «fue causa de que juristas y filósofos del derecho no hayan acertado a ver en este lo que es y no puede menos de ser: un uso entre los usos» ${ }^{88}$. Como defendió Jhering, el derecho no es un concepto elaborado a priori por la razón, es decir, en sentido orteguiano, por la «razón pura». Y eso vale incluso del derecho romano, pues en él hay que distinguir: a) «la realidad jurídica vivida por el romano»; b) «la técnica del derecho o jurisprudencia»; c) la reflexión sobre esta jurisprudencia, «que da una teoría abstracta del derecho, es decir, la llamada filosofía del derecho. En Roma no había filósofos; solo hubo recepción bastante torpona de las doctrinas griegas, comenzando por Cicerón ${ }^{89}$. Y en la misma lección del curso, de donde procede esa cita, Ortega se ve obligado a hacer una aclaración metodológica: no puede llegar a una cabal exposición de qué sea el derecho si previamente no se conoce el «hecho social» que son los «usos». En caso contrario, «hubiera tenido que comenzar desarrollando toda una teoría general del derecho, lo que suele -malamente- llamarse una filosofía del derecho»».

87. Las tres última citas, en El hombre y la gente, OC, X, cap. XI, págs. 292, 305 y 313.

88. El hombre y la gente, OC, X, cap. XI, pág. 293.

89. Sobre una interpretación de la historia universal, cit., OC, IX. Lección IX, págs. 1334-1335, Nota 1.

90. Ibidem, pág. 1335.

Doxa. Cuadernos de Filosofía del Derecho, (2020), 43, pp. 31-58 
¿Qué «filosofía del derecho» tiene Ortega a la vista? Ciertamente la que encuentra entre 1905 y 1907 en sus años de formación en Alemania. En esa época. Europa continental intentaba superar el positivismo jurídico, imperante en la segunda mitad del XIX, que centraba el derecho en la norma imperativa. Podemos suponer, con base, que Ortega conociera esa corriente, pues, con tino, asevera: «No afirmo yo, ni mucho menos, que el derecho sea derecho porque se ejerza imperativamente, sino que lo justo posee, desde luego, la calidad de ser imperable, precisamente porque es derecho" ${ }^{91}$. Pero parece tener solo una ligera noticia del positivismo jurídico a través de un folleto editado en 1907, que contiene un discurso de Richard Loening, con ocasión de un trivial acto académico, en que este profesor se muestra crítico con tal positivismo. La cita carece de acribia $^{92}$.

El positivismo jurídico, negador de toda filosofía, se intentaba superar, en nuestro caso, invocando la vuelta a Kant, en la versión neokantiana de Marburg, universidad en la que recalará Ortega, y en la que recibirá las enseñanzas de Hermann Cohen. A esa misma corriente se adscribía el catedrático de Berlín -universidad también visitada por Ortega en esas fechas-, Rudolf Stammler, «el más ilustre filósofo del derecho en la actualidad ${ }^{93}$. En un artículo publicado en El Sol (10 de febrero de 1918), volviendo la vista atrás, hace balance de lo que esos autores alemanes han significado, y han dejado de significar para él. Partiendo de la censura que, ya en su propio tiempo, se le hiciera al formalismo de su filosofía práctica, esta fue la tarea de sus profesores: «Stammler y Cohen, cada cual según su humor, han intentado vanamente henchir de materia esas formas vacías que son en Kant lo bueno y lo justo». Y aprovecha la oportunidad para ajustar cuentas con él mismo, y con la situación intelectual española: "Otro punto que me interesa subrayar es el excesivo rango que, tanto en este libro como en casi todo lo que se oye en España sobre la filosofía del derecho, ocupa Stammler. Su obra es, sin duda, magistral y venerable. Pero su dirección y la manera fundamental de acercarse a los problemas pertenecen a un pretérito irredimible. No vacilemos en decirlo. El neokantismo fue la doctrina donde nos hemos educado para la filosofía; guardemos gratitud a nuestros maestros. Pero el neokantismo no es la ciencia actual, ni mucho menos la futura». Vana fue la advertencia de Ortega: Stammler se seguirá traduciendo, y en 1922 pronunciará sendas conferencias en las Universidades Central y de Granada ${ }^{94}$. Para cerrar la creciente animosidad de Ortega hacia Stammler, aludiré a la indiscreción

91. Se contiene en: «El genio de la guerra y la guerra alemana», El espectador (1917). OC, Tomo II, pag. $340 \mathrm{Se}$ trata de una crítica a la obra de Max Scheler, Der Genie des Krieges und der deutsche Krieg (1915).

92. Equivoca el nombre del autor (Richard, no Rudolf), no es «von», y trastoca el título: Esencia y raíz del derecho (en el original:Wurzel und Wesen des Rechts, G. Fischer, Jena, 1907). Si bien recomienda que se traduzca. OC Tomo II, pág. 340, nota 1. Las erratas de Ortega las corrige discretamente L. Recaséns, Estudios de Filosofía del Derecho (1936), pág. 530. Más abajo, se completa la cita de Recaséns.

93. Ibidem, Tomo II, pág. 339. Trae a colación a Stammler a propósito de su Teoría del derecho justo, cuyo título cita en alemán.

94. «Un libro sobre la filosofía del derecho», OC, Tomo III, pág. 96. Se trata de una reseña de: Rivera Pastor, F., Lógica de la libertad, F. Beltrán, Madrid, 1918. Sobre la recepción de Stammler en España, remito a mi Discordia, cit., vol. II, págs. 114 y siguientes. 
de Cohen, que le lleva a compartir con Ortega una maledicencia antisemita vertida sobre Stammler, «el famoso filósofo del derecho- no comprendo por qué su fama era tan enorme en el mundo, porque era hombre poco inteligentes ${ }^{95}$. Y, por entender asimismo mal a Cohen, incluye en el anatema a Kelsen, cinco lustros más joven que el catedrático de Berlìn -de cuya teoría del derecho «se han empapuzado lo juristas y filósofos del derecho de todo el mundo»-, si bien, en este caso, sin descender a lo personal: «El derecho no se funda últimamente en algo, a su vez, jurídico como pretendía la extravagancia de Kelsen... sino, en cierta situación total de la vida humana colectiva».

Y entremos ya en la respuesta a la segunda pregunta arriba formulada: ¿Qué entiende Ortega por «sociología»? Una vez que apostató del neokantismo, Ortega nunca fue epígono de nadie. O al menos así quiso estimarse. Partió, hacia 1935, de una pretensión desmesurada: poner en pie "una ciencia fundamental sociológica» ${ }^{96}$. Le animaba a ello el escaso espacio, según su criterio reductor, que en los libros de los pioneros de la sociología ocupaba la cuestión: ¿̇en qué consiste la sociedad? Cuantificando: de la más de cinco mil páginas dedicadas a la sociología por Auguste Comte, «no encontraremos líneas bastantes para llenar una página que se ocupen de decirnos qué entiende por Sociedad»; de los Principios de Sociología, de Herbert Spencer, que no constará de menos de 2.500 páginas, las dedicadas a la misma cuestión no cree que lleguen a cincuenta líneas; hace pocos años aparece Las dos fuentes de la moral y la religión, libro «encantador», un tratado de sociología de 350 páginas, en el que no hay una sola línea, en que Bergson «nos diga formalmente qué son esas sociedades sobre las cuales especula» ${ }^{97}$. A parte de lo problemático que sea incluir a Bergson en este elenco, en sus alrededores se encuentran Max Weber, con su «interindivualidad» como crucial "hecho social», «error» del que ya se habló; y con menos claridad se distancia de Emile Durkheinm, que ya expuso algún elemento característico de los «usos sociales» ${ }^{98}$. Fijado por Ortega el alcance de los usos, como principio de su "sociología», constatamos que, tras una potente arrancada, el bólido se detiene en las primeras vueltas del circuito.

Pero era tal la fe en sí mismo, que Ortega creyó con sus "usos sociales» haber irrumpido en el campo de los fustigados «filósofos del derecho»: "Yo no había pensado nunca en ocuparme del hecho jurídico pero al sumergirme en estos estudios de una sociología radical, que no duda ir al fondo de los fenómenos sociales más profundos, me encontré un buen día sin buscarlo, quererlo o premeditarlo, con toda una filosofía del derecho completamente nueva que hoy anda ya corriente por el mundo porque

95. Sobre una nueva interpretación de la historia universal, cit. OC. Tomo IX, pág. 1321. Y en la misma página: «Stammler a quien Cohen, por ser Stammler judío y haberse convertido, llamaba, hablando conmigo, $A b-$ stammler, es decir, desertor o degenerado». La crítica a Kelsen se encuentra igualmente en esa página. Sobre el tema, Bacigalupo Zapater, E., «Ortega y Gasset sobre Kelsen y el derecho» Revista de estudios orteguianos 33 (2016) 115-131.

96. OC, Tomo V, «Un rasgo de la vida alemana. V. Últimas reflexiones» (La Nación de Buenos Aires, 31 de marzo de 1935), pág. 347.

97. Resumo los párrafos contenidos en El hombre y la gente [Curso 1949-1950], OC, Tomo X, I. «Ensimismamiento y alteración", pág. 141.

98. La referencia a Durkheim, pág. 140. 
algunos de mis discípulos eran precisamente filósofos del derecho. Véanse, por ejemplo, los libros publicados hace ya seis años por el señor Recaséns, quien muy relacionado con los juristas franceses habrá sembrado entre ellos la nueva simiente»" ${ }^{99}$. Veamos los hematomas que la autocomplacencia de Ortega sufre en su contacto con la realidad.

Luis Recaséns Siches, veinte años más joven que Ortega, publicó en 1936, en francés, un artículo sobre los usos ${ }^{100} \mathrm{en}$ el Annuaire de l'Institut International de Philosophie $d u$ Droit et de Sociologie, que no se creó como publicación programada para establecer una colaboración entre ambas disciplinas. Se creo para permitir, en un clima de convivencia internacional, la continuidad en libertad, imposible tras el régimen nazi, del veterano Archiv für Rechts- und Sozialphilosophie. Con este propósito se le dotó de un comité plural ${ }^{101}$. En el mismo año apareció el artículo en castellano ${ }^{102}$. Tras poner de manifiesto la relevancia del tema, citando tres veces el tomo II, de Zweck, y asimilando, en este punto, Kelsen a Max Weber, dedica más interés, precisamente, a Stammler, cuya doctrina, "aunque la considero también fallida, estimo tiene mucho mayor importancia que las anteriores, por haber tratado el problema con más rigor, y por el gran juego que ha dado en la Teoría del Derecho contemporánea» ${ }^{103}$. Parte, para delimitar los usos, de los tres caracteres que el derecho debe tener, para ser definido como «querer entrelazante, autárquico e inviolable", términos que acunó el traductor al español de la obra clásica de Stammler ${ }^{104}$. Mientras el derecho posee esas tres notas, la moral y los usos no las poseen o no en su integridad. Recaséns, acepta la distinción de los tres órdenes, pero no admite una separación radical entre derecho y usos, si bien «en caso de movilidad de fronteras, entre usos sociales y normas jurídicas, es el Derecho al que corresponde la decisión ${ }^{105}$.

Cuatro años más tarde, el discípulo de Recaséns, Luis Legaz Lacambra, al abordar el tema «derecho y usos sociales», sí que cita a Ortega, y además muy oportunamente,

99. OC, IX, El hombre y la gente [Curso 1939-1940], págs. 410 y siguiente.

100. «Les usages et leur differentatiom d'avec les normes juridiques», Annuaire de l'Institut International de Philosophie du Droit et de Sociologie, Tomo II, Sirey, Paris, 1936, págs. 145-163.

101. Presidía el Institut el jurista católico Louis Le Fur (Paris), y era su secretario general Georges Gurvitch (Estrasburgo) y entre los vicepresidentes figuraban Giorgio Del Vecchio (Roma), Arthur Goodhart (Oxford), Hans Kelsen (Ginebra, donde se refugió del antisemitismo nazi), y Luis Recaséns Siches (Madrid). La empresa duró pocos años: la invasión de Francia estaba a la vista.

102. «Las normas de los usos sociales. Su diferenciación de las normas jurídicas», Estudios de Filosofía del Derecho, Bosch, Barcelona, 1936, págs. 109-131.

103. Ibidem, pág. 124.

104. Stammler, R., Tratado de Filosofía del Derecho, traducción de la 2.a ed. alemana por W. Roces, Editorial Reus, Madrid, 1930 (Biblioteca Jurídica de Autores Españoles y Extranjeros) págs. 63 y siguientes.

105. Estudios, cit. pág. 130. Recaséns no menciona, en este contexto, a Ortega, que ya había incluido, dentro de una enumeración, los usos en la conferencia de Valladolid de 1934. Esta omisión la suple en el artículo post-mortem: "José Ortega y Gasset, la sua metafisica, la sua sociologia e la sua filosofia sociale» Rivista Internazionale de Filosofia del Diritto, XXV / 5 (septiembre.octubre 1957) 513-543.

Doxa. Cuadernos de Filosofía del Derecho, (2020), 43, pp. 31-58 
y formula este juicio sobre su maestro: «Nos parece que esta concepción de los usos sociales formulada por Recaséns no difiere en el fondo de la teoría de Stammler.... ${ }^{106}$. Ortega, vemos, no inauguró una sociología, ni inició una «nueva» filosofía del derecho.

\section{BIBLIOGRAFÍA}

Asún Escartín, Raquel, 1981-1982: «La editorial 'La España Moderna’», en Archivium Revista de la Facultad de Filología (Málaga), 31-32: 133-200

Bacigalupo Zapater, Enrique, 2016: «Ortega y Gasset sobre Kelsen y el derecho», en Revista de estudios orteguianos, 33: 115-131

Blasco, Yolanda, 1999: «Notas sobre la recepción de la parte general de Savigny en España», Cuadernos del Instituto Antonio de Nebrija, 2: 11-36

Carreras Artau, Tomás, 1903: «Sobre 'La lucha por el Derecho'», en Revista Jurídica de Cataluña, 9: 297-308

De Azcárate, Gumersindo, 1877: Estudios económicos y sociales

De La Rasilla y del Moral, Ignacio, 2018: In the Shadow of Vitoria. A History of International Law in Spain (1770-1953), Leiden/Boston: Brill/Nijhoff

Delgado Delgado, José A., 2003: «La obra de Theodor Mommsen en Espańa: la traducción española de la 'Römische Geschichte'», en Gerión, 21/2

Elías de TejadA, Francisco, 1965-1966: «Derecho y ley en José Ortega y Gasset», en Anales de la Cátedra Francisco Suárez, 5-6: 109-127

Elías De TejadA, Francisco,1966: «El concepto del derecho de José Ortega y Gasset», en Anuario de Filosofia del Derecho, 12: 37-52

Elías de Tejada, Francisco, 1967: «Ortega y Gasset ante la filosofía del derecho», en: Homenaje al Profesor Giménez Fernández, Universidad Sevilla, vol. I: 373-389

FABIÉ, Antonio María, 1879: Estado actual de la ciencia del derecho, Madrid: Imprenta de la Revista de Legislación

Ganivet, Ángel, 1981: Idearium español (1897), Madrid: Espasa Calpe (Austral 139)

Gibert, Rafael, 1970: «Jhering en España», en Jherings Erbe. Göttinger Symposion zur 150 Wiederkehr des Geburtstags von Rudolph von Jhering, Göttingen: Vandenhoeck \& Ruprecht: 40-67

Gil Cremades, Juan José, 1969: El reformismo español. Krausismo, escuela histórica, neotomismo, Barcelona: Ariel

Gil Cremades, Juan José, 2015: Discordia Concors (I), Granada: Comares

Gil Cremades, Juan José, 2016: Discordia Concors (II), Granada: Comares

Giner de los Ríos, Francisco, 1871: Principios elementares del Derecho

GINER DE LOS Ríos, Francisco, 1876: Estudios filosóficos y religiosos

GonzÁlez, Jerónimo, 1935a: «Jurisprudencia de intereses», Revista Crítica de Derecho Inmobiliario XI /126: 498-521

106. Legaz, L., Introducción a la Ciencia del Derecho, Bosch, Barcelona, 1943. El tema se aborda en págs. 226241. La referencia a Ortega, aludiendo a la "teoría de los complementos de la vida colectiva», desarrollada, como ya vimos, en Historia como sistema. El juicio sobre Recaséns, en pág. 233. 
GonzÁLEz, Jerónimo, 1935b: «La escuela de Tubinga», en Revista Crítica de Derecho Inmobiliario XI /128: 561-575

GonZÁlez VicÉn, Felipe, 1991: «Los usos sociales. Un ensayo de sociología descriptiva», en Anuario de Filosofía del Derecho, 8:481-493

Heuss, Alfred, 1965: Theodor Mommsen und das 19. Jahrhundert, Kiel, Hirt

Hierro S. y Pescador, José, 1965: El derecho en Ortega, Madrid: Ediciones de la Revista de Occidente

JHERING, Rudolf von, 1857: «Unsere Aufgabe», en Jahrbuch des heutigen römischen und deutschen Recht, 1

JHERING, Rudolf von, 1858: Geist des römischen Rechts auf den verschiedenen Stufen seiner Entwicklung (1. a edición digitalizada en Deutsche Digitale Bibliothek)

JHERING, Rudolf von, 1866: Geist des römischen Rechts auf den verschiedenen Stufen seiner Entwicklung, Vorwort IX, Leipzig: Breitkopf und Härtel

Jhering, Rudolf von, 1882: El combate por el derecho (trad. Alfonso de Pando y Gómez), Madrid: Establecimiento Tipográfico «La Moderna», XIV-84

JHERING, Rudolf von, 1891: El espiritu del derecho romano en las distintas fases de su desarrollo, (versión española con la autorización del autor y notas por Enrique Príncipe y Satorres), Madrid: Librería Editorial de don Carlos Bailly-Baillière, Tomo I, XV-414; Tomo II, 343; Tomo III, 405; Tomo IV, 469

JHERING, Rudolf von, 1892: Teoría de la posesión. El fundamento de la protección posesoria, Estudio preliminar por Adolfo Posada, Madrid: Imprenta de la Revista de Legislación, XXVII-228

Jhering, Rudolf von, 1895: Cuestiones jurídicas. Del interés en los contratos. La posesión: teoría simplificada. Casos jurídicos (trad. Adolfo Posada), en La Espańa Moderna, Madrid: Biblioteca de Jurisprudencia, Filosofía e Historia

JHERING, Rudolf von, 1896a: La voluntad en la posesión: con la crica del método jurídico reinante, (trad. Adolfo Posada), Madrid: Imprenta de la Revista de Legislación (Biblioteca jurídica de autores españoles y extranjeros)

Jhering, Rudolf von, 1896b: Prehistoria de los indoeuropeos, estudio preliminar de Adolfo Posada, Madrid: Librería de Victoriano Suárez

JHering, Rudolf von, 1905: Der zweck im recht (Vol. 2), Breitkopf und Härtel.

JHERING, Rudolf von, 1911: El fin en el derecho (trad de L. Rodríguez), en B. Rodríguez Serra (ed.), Madrid: Biblioteca de Filosofía y Sociología

JHERING, Rudolf von, 1933: Jurisprudencia en broma y en serio, (trad. de la tercera edición alemana por R. Riaza), Madrid: Revista de Derecho Privado

JHering, Rudolf von, 1961: El fin en el derecho (trad. D. Abad de Santillán), México: Cajica

Jhering, Rudolf von, 1985: La lucha por el derecho (trad. A. Posada, prólogo de L. Alas), Madrid: Civitas

JHERING, Rudolf von, 1987: Bromas y veras en la ciencia jurídica, Madrid: Civitas

Jhering, Rudolf von, 1993: El derecho en la vida cotidiana (trad. E. Valiño), Tirant lo Blanch

JHERING, Rudolf von, 2002: ¿Es el derecho una ciencia? (trad. F. Fernández-Crehuet), Comares

JHERInG, Rudolf von, 2008: Sobre el nacimiento del sentimiento juridico (trad. F. FernándezCrehuet), Trotta

Krause, Karl Christian Friedrich, 1860: Ideal de la Humanidad para la vida (con introducción y comentarios por. D. Julián Sanz del Río), Madrid: Imprenta de Manuel Galiano 
Krause, Karl Christian Friedrich, 1871: Ideal de la Humanidad para la vida (con introducción y comentarios de D. Julián Sanz del Río), Madrid: Imprenta de F. Martínez García

Legaz Lacambra, Luis, 1943: Introducción a la Ciencia del Derecho, Barcelona: Bosch

Legaz Lacambra, Luis, 1960: «El derecho internacional en el pensamiento de José Ortega y Gasset», en Revista de Estudios Politicos 111: 5-42

Lloredo Alix, Luis, 2014: «La recepción de Rudolf von Jhering en Europa: un estudio histórico-comparado", en Revista telemática de Filosofía del Derecho 17: 203-250

López Medel, Jesús, 1960: Ortega en el pensamiento jurídico contemporáneo, Secretaría General del Movimiento, Madrid

Losano, Mario y Ermanno Bonazzi, 1978: Bibliografie di Jhering e Gerber, Milan: Giuffrè Editore: 38 y 39

Martínez-Pinna, Jorge (coord.), 2005: En el Centenario de Theodor Mommsen (1817-1903). Homenaje desde la Universidad Española, Málaga/Madrid: Universidad de Málaga/Real Academia de la Historia

Miguel Alonso, Aurora y Martínez Neira, Manuel y González Paz, Andrea, 2018: Doctores en derecho por la Universidad Central. Catálogo de tesis doctorales 1847-1914, Madrid: Universidad Carlos III

Mommsen, Theodor, 1876-1877: Historia de Roma, 9 vols (trad. de A. García Moreno; pról. de F. Fernándes y González), Madrid, Góngora

Mommsen, Theodor, 1893: "Compendio del derecho público romano» (trad. de P. Dorado Montero), en La España Moderna, S.A, Madrid

Mommsen, Theodor, 1945: El mundo de los Césares (trad. W. Roces), México: Fondo de Cultura Económica

Monereo, José Luis, 1998: "Jhering, ensayo de explicación: introducción a su pensamiento jurídico», en El espiritu del derecho romano, Granada: Comares: XCI-CXIII

Motтe, Oliver, 1983: Savigny et la France, Berne: F. Lang

Navarro Flores, Martín, 1901: «Sobre el concepto del derecho según Jhering», en RGLJ 98: 581-590

Neila, Manuel, 2011: «Fernando Vela, la música callada de la traducción», en Cuadernos Hispanoamericanos 732: 91-122.

Olivart, Ramón María de Dalmau, 1884: La posesión. Apuntes y fragmentos de una nueva teoría posesoria, Barcelona: Imprenta de J. Jepús

Ortega y Gasset, José, 2004-2010: Obras Completas, Madrid: Taurus/Fundación José Ortega y Gasset

Pérez de la Dehesa, Rafael, 1996: Política y sociedad en el primer Unamuno, Madrid: Ciencia Nueva

Pérez-Luño, Antonio Enrique, 2005: «Hegel y Ortega. Meditación sobre los presupuestos historiográficos de la Filosofía del derecho», en Meditaciones sobre Ortega y Gasset: 523-568

Recaséns Siches, Luis, 1936a: «Les usages et leur differentatiom d'avec les normes juridiques», en Annuaire de l'Institut International de Philosophie du Droit et de Sociologie, Tomo II, Paris: Sirey

Recaséns Siches, Luis, 1936b: Estudios de Filosofía del Derecho, Barcelona: Bosch

Recaséns Siches, Luis, 1957: "José Ortega y Gasset, la sua metafisica, la sua sociologia e la sua filosofia sociale», en Rivista Internazionale de Filosofia del Diritto, XXV / 5: 513-543

Revista General de Legislación y Jurisprudencia (RGLJ); 1853, 2:128; 1854, 3: V; 1878, 52:126 
Rivera Pastor, Francisco, 1918: Lógica de la libertad, Madrid: F. Beltrán

Robles, Gregorio, 2005: «La filosofía jurídica de Ortega: el derecho como uso social y la justicia como valor», en Llano, F. H.; Castro, A (eds.), Meditaciones sobre Ortega y Gasset, Madrid: Tébar: 569-592

RodríGuez DE CEPEDA, Rafael, 1893: Exposición y juicio crítico de algunas teorías modernas del derecho, Valencia: Imprenta de Nicasio Ríus Monfort

Romero Recio, Mirella, 2005: «Traducciones y ediciones de la obra de Mommsen en España (1876-1905)», Universidad de Málaga

Ruiz Ballón, Antonio, 2013: Pedro Gómez de la Serna (1806-1871). Apuntes para una biografía jurídica, Madrid: Universidad Carlos III

Savigny, Friedrich Carl von, 1845: Tratado de la posesión según los principios de Derecho romano, Madrid: Imprenta de la Sociedad Literaria y Tipográfica

SAvignY, Friedrich Carl von, 1878-1879: Sistema del derecho romano actual, (trad. por Ch. Guénoux), vertido al castellano por J. Mesía y M. Poley, y prólogo de M. Durán y Bas, 5 vols, Madrid: F. Góngora y Cía editores (Biblioteca Universal. Sección Jurídica)

Savigny, Friedrich Carl von, 1896: De la vocación de nuestro siglo para la legislación y para la ciencia del derecho (prólogo A. Posada). en La Espańa Moderna, Madrid (Biblioteca de jurisprudencia, filosofía e historia)

Serrano Migallón, Fernando, 2003: Los maestros del exilio español en la Facultad de derecho, México D.F: Porrúa/ Facultad de Derecho de la UNAM

Stammler, Rudolf, 1930: Tratado de Filosofía del Derecho, (trad. de la 2. a ed. alemana por W. Roces), Madrid: Editorial Reus (Biblioteca Jurídica de Autores Españoles y Extranjeros)

Torres Campos, Manuel, 1876: Catálogo sistemático de las obras existentes en la Biblioteca de la Academia de Jurisprudencia y Legislación, Madrid: Imprenta del Ministerio de Gracia y Justicia

Torres Campos, Manuel, 1883: Bibliografía española contemporánea del Derecho y de la Política Tomo I 1800-1880, Madrid: Fernando Fe

Torres Campos, Manuel, 1897: Bibliografía española contemporánea del Derecho y de la Política Urbano Guerrero, José, 1906: El sistema jurídico de Jhering (tesis doctoral)

Weber, Max, 1964: Economía y sociedad, México: Fondo de Cultura Económica

Whitman, James Q., 1870: «Jhering parmi les Français, 1870-1918, en La science juridique française et la science juridique allemande de 1870 à 1918

Whitman, James Q., 1990: The Legacy of Roman Law in the German Romantic Era, Princeton: Princeton University Press

Wolf, Eric, 1963: Grosse Rechtsdenker in der deutschen Geistesgeschichte, Mohr

Yeves Andrés, Juan Antonio, 2002: La España Moderna. Catálogo editorial. Índices de la Revista, Madrid: Libris

$\triangle \quad$ DOXA 43 (2020)

Doxa. Cuadernos de Filosofía del Derecho, (2020), 43, pp. 31-58 